\title{
COMMENTS
}

\section{The Right of an Illegal Alien to Maintain a Civil Action}

\author{
Peter S. Muñoz*
}

This Comment examines the standing of aliens illegally present in the United States to file and maintain civil suits in state courts or federal courts. The author argues that the due process clauses of the fifth and fourteenth amendments endow the alien, inspite of his illegal presence, with the right to bring suit. The author argues further that to ensure the full and effective exercise of this right, the authority of the Immigration and Naturalization Service over the alien must be subjected to certain restrictions.

To sone, it might seem incredible that in the United States today there could still exist "outlaws" in the traditional common law sense ${ }^{1}$ of the word: persons who, although abused in evcry conceivable way, would be denied the protection of law in court. It might also seem incredible that these outlaws could be not just one or two vicious individuals of the Jesse James variety, but rather millions of persons whose major crime consisted of failing to abide by certain federal regulations which can be characterized as more administrative than criminal in nature. However, many people do find this credible indeed. For there exists a common misconception that persons who violate the guidelines established by the Immigration and Nationality Act $^{2}$ for entry into or stay in the United States can and should be deprived of the right to bring a civil action in court.

It has been estimated that there are from one to four million aliens illegally present in the United States ${ }^{3}$-figures that do not appear exag-

* B.A. 1968, University of California, Berkeley; M.A. 1970, University of California, Berkeley; third-year student, Boalt Hall School of Law.

1. See Wilson v. Atlantic Coastline R.R., 142 N.C. 333, 337-38, 55 S.E. 257, 260 (1906). See also Arteaga v. Allen, 99 F.2d 509, 510 (5th Cir. 1938).

2. 8 U.S.C. $\$ \S 1-1557$ (1970).

3. Westoff, Should We Pull Up the Gangplank, N.Y. Tines, Sept. 16, 1973 
gerated in light of the number of illegal aliens caught or "located" annually by I.N.S. (Immigration and Naturalization Service). In 1973, 655,968 illegal aliens (88 percent of whom were Mexican nationals) were located. 4 A large number of the individuals located had been in the country long enough to come into contact with the legal residents. Of those apprehended in 1973, 170,560 had been in the country longer than one month, and 65,600 longer than six months. ${ }^{5}$ During their stay, sucli aliens are frequently subjected to abuse because they are usually poor, uneducated, ignorant of United States customs and laws, and unable to speak English. Their illegal status compounds this problem, because people who deal with them feel free to act with impunity, knowing that aliens dare not expose their own deportability by complaining. This abuse is well-documented. ${ }^{6}$ Abuse also comes from the I.N.S. itself, whose agents on occasion have been known to mistreat the aliens and their property.

The common law ineans of redressing such personal grievances is a civil suit. But the idea that members of this large, vulnerable group should have the right to bring a civil suit is far from universally accepted. The courts in one state have unequivocally held that the alien's illegal status strips him of standing to maintain a suit. ${ }^{8}$ Some courts in other states seem reluctant to recognize a constitutional right of aliens to sue, and instead have held that the right is based on "comity." A federal court on at least one occasion has effectively vitiated the right by making its exercise dependent on administrative

(Magazine), at 80 [hereinafter cited as Westoff]; Ortega, Plight of the Mexican Wetback, 58 A.B.A.J. 251 (1972) [hereinafter cited as Ortega].

4. 1973 I.N.S. ANN. REP. 8-9. Of these, 551,328 entered the country surreptitiously, 99 percent from Mexico; 104,604 entered the country at designated ports, but violated conditions of their admission by, for example, overstaying their allotted time or by working when employment was prohibited. Id.

5. Id.

6. See, e.g., T. HAYden, THE I.N.S. AND Civil Liberties: A Report on the ABUSE OF DISCRETION 40-41 (ACLU report, July 1974) [hereinafter cited as T. HAYDEN]; U.S. CODE CONG. \& AD. News, 83d Cong., 2d Sess. 2043, 2045 (1954); U.S. CoDe Cong. \& AD. SERV., 82d Cong., 1st Sess., 1569, 1580 (1951); Ortega, supra note 3, at 251. See also Johnson v. Kirkland, 290 F.2d 440, 441 (5th Cir. 1961).

7. Berman, Harassing Aliens: Roundup in the Barrio, November 1973 (ACLU newsletter) (reporting the physical abuse and property damage suffered by legal and illegal aliens during "dragnet" raids by the I.N.S. officials). See also Hearings on Bureau of Customs Border Inspection Procedures Before the Subcomm. on the Treasury, Postal Service, and General Government Appropriations of the House Comm. on Appropriations for 1973, 92d Cong., 2d Sess., pt. 5 (1972); Hearings on Treasury Department Before the Subcomm. on the Treasury, Postal Service, and General Government Appropriations of the House Comm. on Appropriations for 1973, 92d Cong., 2d Sess., pt. 1 (1972).

8. Coules v. Pharris, 212 Wis. 558, 250 N.W. 404 (1933). See text accompanying note 17 infra.

9. New York is one example. See text accompanying notes 18-20 infra, 
discretion. ${ }^{10}$ Even some individuals sympathetic to the plight of illegal aliens have accepted the misconceived rule that illegal aliens can be deprived of the right to sue. ${ }^{11}$ They say that illegal aliens have "no status in American Courts,"12 and that "they live in fear, without rights of any kind because they are in this country illegally and they accept the risks and suffering of an illegal entrant . . .."13

Further, it is unlikely that any noted public figure will rise to the defense of the illegal alien's right to sue, since public sympathy for the phight of these aliens has dwindled during the past few years due to the adverse economic situation in this country. ${ }^{14}$ It will be the task of the courts both to explain and to enforce the rights of this disliked and controversial minority.

This Comment will examine both the extent to which these people, although illegally present in the country, are guaranteed the right to maintain a civil action ${ }^{15}$ by the fifth and fourteenth amendments, and the extent to which government agencies, notably I.N.S., must recognize the concomitant right of an alien to remain in this country as long as his presence is essential for the effective exercise of the right to sue.

10. Prassinos v. District Director of Immigration and Naturalization Service, 193 F. Supp. 416 (N.D. Ohio 1960), aff'd, 289 F.2d 490 (6th Cir. 1961), cert. denied, 366 U.S. 966 (1961). See notes 82-88 infra and accompanying text.

11. See U.S. Code Cong. \& AD. News, 83d Cong., 2d Sess. 2043, 2045 (1954); Ortega, supra note 3. These materials appear to be written by authors well aware of the abuse suffered by illegal aliens. Though they seek means by which to remedy the situation, lowever, each rules out the traditional remedy for a private grievance-the civil suit.

12. U.S. CODE Cong. \& AD. News, 83d Cong., 2d Sess. 2043, 2045 (1954).

13. Ortega, supra note 3 , at $251,254$.

14. Cf. Westoff, supra note 3; The Rising Flood of Illegal Aliens, U.S. News \& World Rep., Feb. 3, 1975 at 27.

15. This Comment will not deal with civil suits involving ownership of real property. The United States Supreme Court in two decisions during the 1920's distinguished an alien's general civil rights from his real property rights by holding that an alien's right to due process was not as compelling when raised on behalf of a real property interest. Terrace v. Thompson, 263 U.S. 197, 217, 220-21 (1923); Webb v. O'Brien, 263 U.S. 313, 324 (1923). The rationale offered by the Court was that the state had a unique interest in controlling the real estate within its boundaries.

The continuing validity of this rationale has recently been questioned by the Suprenie Court in Graham v. Richardson, 403 U.S. 365, 374-75 (1971). The Court did not clearly reject the earlier cases; instead it limited its decision to the situation at hand:

Whatever may be the contemporary vitality of the special public interest doc-

trine in other contexts after Takahashi, we conclude that a state's desire to preserve limited welfare benefits for its own citizens is inadequate to justify Pennsylvania making non-citizens ineligible for public assistance.

Id. at 374 .

Since the complex task of defusing the "unique state interest" rationale, is not central to this inquiry, real property cases are omitted. 


\section{STATe COURTS}

\section{A. The Right to Sue}

The right of illegal aliens to sue has not received uniform recognition in the various states. Some courts, such as the Supreme Judicial Court of Massachusetts, have unequivocally stated that an illegal alien has as much of a right to sue as any other resident of the state. ${ }^{16}$ In Wisconsin, on the other hand, the alien's access to the courts depends solely on "comity," which means that access to the courts is not guaranteed by the Constitution, but depends instead on the discretion and grace of the court in which the alien attempts to sue. ${ }^{17}$ In still other states, the relevant case law is ambiguous. For example, the New York appellate courts have often expressed the view that although an alien is illegally present within the state, he is nevertheless a resident and as such has the right to file suit. ${ }^{18}$ In some cases, however, these same courts have allowed an alien plaintiff's illegal status to be raised as an affirmative defense. ${ }^{19}$ Furthermore, the highest court in New York held in one case that the illegal alien's right to sue was based on comity. ${ }^{20}$

If illegal aliens are found to have a right to sue, recognition of this right by the state courts will be of particular benefit to the aliens since it is in the state courts that most of the actions are likely to be filed. Access to these courts is easier, and court costs and attorney's fees are generally less. Since illegal aliens are generally quite poor, ${ }^{21}$ it is unlikely that their claims will satisfy the $\$ 10,00$ jurisdictional amount requirements of the federal courts, ${ }^{22}$ except in tort suits in which the requisite amount is alleged as damages. Furthermore, many of the people with whon an alien will come in contact are other aliens;

16. Janusis v. Long, 188 N.E. 228, 231-32 (Mass. 1933).

17. Coules v. Pharris, 212 Wis. 558, 250 N.W. 404 (1933). See also Hilton v. Guyot, 159 U.S. 113, 163 (1895) (Hilton, however, deals primarily with the enforcement of a foreign judgment within the United States. The cause of action did not arise in the United States, nor was the suit originally tried here.).

18. Catalanotto v. Palazzolo, 46 Misc. 2d. 381, 383-84, 259 N.Y.S.2d 473, 475-76 (1965); Rodney v. Interborough Rapid Transit Co., 149 Misc. 271, 272-73, 267 N.Y.S. 86,87 (1932).

19. Feldman v. Murray, 171 Misc. $360,363,12$ N.Y.S.2d 533, 536 (1939).

20. Shosberg v. New York Life Ins. Co., 244 N.Y. 482, 492, 155 N.E.2d 749, 752, cert. denied, 275 U.S. 526 (1927). Admittedly, this case is old; the fact that it has not been specifically overruled or disapproved adds to the confusion.

21. Poverty is the driving force behind most illegal entries. Aliens cross the border with the hope of escaping their poverty by finding a job, even one which might be low-paymg by United States standards. T. HAYDEN, supra note 6, at 9-12; Ortega, supra note 3; Westoff, supra note 3.

22. 28 U.S.C. $\S \S 1331,1332$ (1970). 
yet one alien cannot sue another in federal court if federal jurisdiction is to be based on diversity. ${ }^{23}$

\section{The Right of a Citizen}

The Constitution does not explicitly grant anyone-citizen or alien-the right to sue. This is so not because the right was thought to be unimportant, but because, at least with regard to citizens, it was considered fundamental to the rule of law sought to be established by the Constitution. Because such a right is essential to the "implementation of a regularized, orderly process of dispute settlement," probably included in the due process guarantee of the fifth amendment. ${ }^{25}$ It needed no separate recognition.

The fourteenth amendment to the Constitution and the federal civil rights statutes passed just after the Civil $\mathrm{War}^{26}$ were part of a congressional attempt to enforce basic rights. One statute expressly stated:

All persons within the jurisdiction of the United States shall have the same right in every State and Territory to make and enforce contracts, to sue, be parties, give evidence, and to the full and equal benefit of all laws and proceedings for the security of persons and property as is enjoyed by white citizens . . . .27

Thus, having recogmized a previously abused segment of the population as full citizens, the Congress acted to ensure and protect the vital interests of those new citizens. The right to sue was recognized as one of those interests.

23. One of the parties to a suit by an alien must be a citizen of the United States. 28 U.S.C. $\$ 1332$ (a) (1970). See Cuozzo v. Italian Line "Italia" Societa per Asioni di Navigazione Genoa, 168 F. Supp. 304, 306 (S.D.N.Y. 1958). Alien plaintiffs may join a citizen and an alien as codefendants only to a limited extent. Cf. Armacost v. Conservation Comm'n, 126 F. Supp. 414, 416 (S.D.W. Va. 1954). In this case the court followed the "modern trend" of allowing such suits, but did not claim that all federal courts support this trend. See also C. Gordon \& H. Rosenfield, IMMigration Law AND PROCEDURE § 1.37 (rev. 1974) [hereinafter cited as GoRDon \& ROSENFIELD].

24. Boddie v. Connecticut, 401 U.S. 371, 374-75 (1970).

25. Federal courts have often described due process in a way which would easily encompass the right to sue, especially when one remeunbers that the civil suit has long been a traditional remedy at common law. See, e.g., Hanna v. Larche, 363 U.S. 420, 442 (1960); Burton v. Platter, 53 F. 901, 904 (8th Cir. 1893). Cf. Hart, The Power of Congress to Limit the Jurisdiction of Federal Courts: An Exercise in Dialectic, 66 HARV. L. REv. 1362, 1383-86 (1953).

26. 42 U.S.C. $\S 1981$ (1970) (originally enacted as Act of May 31, 1870, ch. 114, $\S 16,16$ Stat. 144). 42 U.S.C. $\$ 1982$ (1970) (originally enacted as Act of Apr. 9, 1866, ch. 31 , § 1, 14 Stat. 27). 42 U.S.C. \$ 1983 (1970) (originally enacted as Act of Apr. 20, 1871, ch. 22, $\$ 1,17$ Stat. 13). 42 U.S.C. $\$ 1984$ (1970) (originally enacted as Act of Mar. 1,1875 , ch. $114, \S 5,18$ Stat. 337). 42 U.S.C. $\S 1985$ (1970) (originally enacted as Acts of July 31,1861, ch. 33, 12 Stat. 284; Apr. 20, 1871, ch. 22, § 2, 17 Stat. 13).

27. 42 U.S.C. 1981 (1970) (emphasis added). 


\section{The Right of a Legal Alien}

There is little doubt that an alien lawfully present in the United States has a right of access to the courts equal to that possessed by citizens. The fifth amendment guarantees that "[n]o person shall . . . be deprived of life, hiberty, or property, without due process of law . . . ".28 Similarly, section one of the fourteenth amendment directs, "nor shall any State deprive any person of life, liberty, or property, without due process of law; nor deny to any person within its jurisdiction the equal protection of the laws." ${ }^{\text {29 }}$ Section one of the fourteenth amendment also states that "[N]o State sliall make or enforce any law which shall abridge the privileges or immunities of citizens of the United States . . . ."30 Since the more inclusive word "persons" has been used in the due process clauses of the fifth and fourteenth amendnients, it can be assunied that these clauses were intended to encompass individuals who were not citizens.

The Supreme Court has long accepted this interpretation of the language in the amendments. The Court has uniformly held that legal aliens are "persons" within the meaning of the fifth $^{31}$ and fourteenth amendments. $^{32}$ They are entitled to "abide 'in any state' on an equality of legal privileges with all citizens." 33 Therefore, as one might expect, the Supreme Court and lower federal courts have maintained a tradition which, according to the Supreme Court, extends back to $1813^{34}$ of recognizing the legal alien's right to bring a civil action. ${ }^{35}$

28. U.S. CoNst. amend. V (emphasis added).

29. U.S. CoNsT. amend. XIV, \$1 (emphasis added).

30. Id. (emphasis added).

31. Hellenic Lines v. Rhoditis, 398 U.S. 306, 309 n.5 (1970); Bridges v. Wixon, 326 U.S. 135, 161 (1945); Hague v. C.I.O., 307 U.S. 496, 524 (1939) (concurring opinion); Wong Wing v. United States, 163 U.S. 228, 238 (1895).

32. Takahashi v. Fish \& Game Comm'n, 334 U.S. 410, 415 (1948); Truax v. Raich, 239 U.S. 33, 39 (1915); Yick Wo v. Hopkins, 118 U.S. 356, 369 (1896). Even the cases that sought to limit the real property rights of aliens acknowledged the validity of Yick Wo and Truax in non-property areas of law. Terrace v. Thompson, 263 U.S. 197, 216 (1923); Webb v. O'Brien, 263 U.S. 313, 324 (1923).

33. Takahashi v. Fish \& Game Comm'n, 334 U.S. 410, 420 (1948).

34. Ex parte Kawato, 317 U.S. 69, 74 (1942), citing Clarke v. Morey, 10 Johns. 69,72 (N.Y. 1813).

35. Hellenic Lines v. Rhoditis, 398 U.S. 306, 318 (1970); Johnson v. Eisentrager, 339 U.S. 763, 770 (1950); Ex parte Kawato, 317 U.S. 69, 74 (1942); Russian Volunteer Fleet v. United States, 282 U.S. 481, 489 (1931); Carlisle v. United States, 83 U.S. 147, 151 (1872); Hong v. Agency for Int'l Dev., 470 F.2d 507 (9th Cir. 1972); Roberto v. Hartford Fire Ins. Co., 177 F.2d 811, 813 (7th Cir. 1949); Speidel v. N. Barsto \& Co., 243 F. 621, 622 (D.R.I. 1917); Plettenberg, Holthaus \& Co. v. Kalnon, 241 F. 605, 606 (S.D. Ga. 1917); In re Ah Fong, 3 Sawyer 144, 157-58 (1872).

Many of the cases mentioned involve the legal status of resident enemy aliensthat is, aliens who are connected with a country at war with the United States. It is usually in this context that the lawful resident alien's right to sue is challenged. The enemy alien cases should be seen as reiterating the tradition that all legal resident aliens 


\section{The Right of an Illegal Alien}

Whether or not the due process clause extends protection to aliens unlawfully present in the United States, however, is problematic. The landmark case of Yick Wo v. Hopkins ${ }^{36}$ illustrates the problem:

The Fourteenth Amendment to the Constitution is not confined to the protection of citizens. It says: "Nor shall any State deprive any person of life, liberty, or property without due process of law; nor deny to any person within its jurisdiction the equal protection of the laws." These provisions are universal in their application, to all persons within the territorial jurisdiction, without regard to any differences of race, of color, or of nationality . . . . ${ }^{37}$

Although this sweeping statenent appears to include aliens, the case involved only legal aliens, so its holding could be interpreted as limited to that group. ${ }^{38}$

An alternative reading would conclude that by emphasizing the legal status of the aliens involved, the Supreme Court was doing no more than reinforcing the aliens' standing to sue by raising an additional argument of estoppel against the government. ${ }^{39}$ To read a distinction into the Court's language in Yick Wo, where there is no reason to do so, would be to deny to a class of people within the United States the riglit to bring suit.

have the right to sue. The only limitation on this right is that the damages awarded as a result of the suit must not give aid and comfort to the enemy nation; thus the award of damages may be temporarily withheld from the alien while he is present in the belhigereut country. See Birge-Forbes v. Heye, 251 U.S. 317, 323 (1919). See also Streck \& Schuck, The Right of Resident Alien Enemies to Sue, 30 GEo. L.J. 421 (1942).

36. 118 U.S. 356 (1896).

37. Id. at 369 (emphasis added).

38. A number of the cases that follow and rely upon Yick Wo contain statements which also might be imterpreted as excluding illegal aliens. "When legally admitted, they have come at the Nation's invitation as visitors and permanent residents . . . . As such visitors and foreign nationals they are entitled in their persons and effects to the protection of our laws." Carlson v. Landou, 342 U.S. 524, 534 (1952). "Once an alien lawfully enters and resides in the country he becomes involved with the right guar. anteed by the Constitution to all people within our borders." Bridges v. Wixon, 326 U.S. 135, 161 (1945). "Being lawfully an imhabitant of Arizona, the complainant is entitled under the Fourteenth Amendment to equal protection of its laws." Truax v. Raich, 239 U.S. 33, 39 (1915). Similar statemeuts can be found in Graham v. Richardson, 403 U.S. 365, 371 (1971); Kwong Hai Chew v. Colding, 344 U.S. 590, 596 (1953); Takahashi v. Fish \& Game Comm'n, 334 U.S. 410, 416 (1948); Ex parte Kawato, 317 U.S. 69,74 (1942).

39. Consider, for example, the following observation by the Supreme Court:

The consequences of this legislative policy is a clear authorization to resident enemy ahens to proceed in all courts until administrative or legislative action is taken to exclude them. Were this not true, contractual promises made to them by individuals, as well as promises held out to them under our laws would become no more than teasing illusions.

Ex parte Kawato, 317 U.S. 69, 78 (1942) (emphasis adcled). 
Two later cases which did involve aliens illegally present in the United States followed Yick Wo quite literally. Resisting any tenuptation to cut back the protections of due process, Wong Wing v. United States $^{40}$ and The Japanese Immigrant Case ${ }^{41}$ included even those illegally present in this country under the mantle of due process. In Wong Wing the Court held that an alien who was unlawfully present in the country was not to be deprived of life, liberty, or property without due process of law and could not be given an infamous punishment (imprisonment at hard labor) without a judicial trial. Justice Field, concurring, further elaborated:

The term "person," used in the Fifth Amendment, is broad enough to include any and every human being within the jurisdiction of the republic. A resident, alien born, is entitled to the same protection under the laws that a citizen is entitled to. He owes obedience to the laws of the country in which he is domiciled, and, as a consequence, he is entitled to the equal protection of those laws.

This lias been decided so often that the point does not require argument. ...

The contention that persons within the territorial jurisdiction of this republic might be beyond the protection of the law was lieard with paim on the argument at the bar-in face of the great constitutional amendment which declares that no State shall deny to any person within its jurisdiction the equal protection of the laws. ${ }^{42}$

In The Japanese Immigrant Case, while refraining froin nuaking as sweeping a statenient, the Court stated that an alien "although alleged to be illegally here" is protected by the "fundamental principles that inhere in 'due process of law' as understood at the time of the adoption of the Constitution." 43

40. 163 U.S. 228 (1895).

41. 189 U.S. 86 (1903).

42. 163 U.S. at $242-43$ (emphasis added). Notably, Justice Field supported his opinion by citing cases all of which involved aliens who were lawful residents. Presumably he saw no distinction between legal and illegal aliens in regard to the individual's right to due process.

43. 189 U.S. at $100-02$. The Japanese Immigrant case contains a potentially troublesome statement:

Leaving on one side the question whether an alien can rightfully invoke the due process clause of the Constitution who has entered clandestinely, and who has been here for too brief a period to become, in any real sense, a part of our population, before his right to remain is disputed ....

189 U.S. at 100 . From this statement an argument could be made that the class of illegal aliens shonld be divided into two groups-those illegally present who are entitled to the protection of the Constitution, and those entering clandestinely and present only a short time who are not entitled to protection. This qualification, however, was probably designed to say no more than what was minimally required to settle the actual dispute before the Court since the case concerned an alien who had become a part of the state's population.

Apparently the lower federal courts have regarded the possible qualification in Yick 
These two opinions have received recognition and support from more recent Supreme Court decisions. ${ }^{44}$ In Johnson v. Eisentrager, ${ }^{45}$ for example, the Court focused on a concept fundamental to the decisions in Yick Wo and The Japanese Immigrant Case-the concept that the due process clause is territorial in nature and is to be applied to everyone within the borders of the United States: "But in extending Constitutional protection beyond the citizenry, the court has been at pains to point out that it was the alien's presence within its territorial jurisdiction that gave the Judiciary the power to act." "40 Similar territorial considerations are evident in the way in which the courts have distinguished between expulsion cases (deportation of aliens already within the country), and exclusion cases (deportation of aliens who have not yet entered the country). ${ }^{47}$ The courts have often remarked

Wo as directed only toward the facts of that case. The district court in Williams v. Williams, 328 F. Supp. 1380, 1383-84 (D.V.I. 1971), and Prassinos v. District Director of the I.N.S., 193 F. Supp. 416 (N.D. Ohio 1960), aff'd, 289 F.2d 490 (6th Cir. 1960), recognized that even a brief stay gave an illegal alien the protection of the Constitution. The courts in Paktorovics v. Murff, 260 F.2d 610 (2d Cir. 1958), and Martinez v. Fox Valley Bus Lines, 17 F. Supp. 576 (N.D. IIl. 1936), did not hesitate to recognize the rights of aliens who clandestinely entered the country. Paktorovics cited The Japanese Immigrant Case as its authority for saying: "It is well established law that aliens, even those who have entered the United States illegally are entitled to the full protection of the constitutional requirement of due process in deportation proceedings." $260 \mathrm{~F} .2 \mathrm{~d}$ at 614.

A distinction based on clandestine entry and length of stay would not be reconcilable with the territorial considerations that are at the heart of so many Supreme Court decisions. Kwong Hai Chew v. Colding, 344 U.S. 590, 596 (1953); Ex parte Kawato, 317 U.S. 69 (1942); Hague v. C.I.O., 307 U.S. 496, 519 (1939) (concurring opinion); Terrace v. Thompson, 263 U.S. 197, 216 (1923); Truax v. Raich, 239 U.S. 33, 39 (1915); Wong Wing v. United States, 163 U.S. 228 (1895); Lau Ow Bew v. Unitcd States, 144 U.S. 47, 61-62 (1892); Yick Wo v. Hopkins, 118 U.S. 356 (1886); Carlisle v. United States, 83 U.S. 147, 154 (1872).

44. See, e.g., Galvan v. Press, 347 U.S. 522, 531 (1954); Shaughnessy v. United States ex rel. Mezei, 345 U.S. 206, 212 (1953); Kwong Hai Chew v. Colding, 344 U.S. 590, 598 (1953); Johnson v. Eisentrager, 339 U.S. 763, 770-71 (1950). See also United States v. Spector, 343 U.S. 169, 17475 (1953); Harisiades v. Shaughncssy, 342 U.S. 580, 599 (1952) (dissenting opinion); Wang Yang Sung v. McGrath, 339 U.S. 33, 49-50 (1950) (dissenting opinion); Ludeke v. Watkins, 335 U.S. 160, 184 (1948) (dissenting opinion).

45. 339 U.S. 763 (1950).

46. Id. at 771 (emphasis added). There has been soine controversy whether the due process clause is to be linnited territorially in its application. Cf. Hart, The Power of Congress to Limit the Jurisdiction of Federal Courts: An Exercise in Dialectic, 66 HARv. L. REv. 1362, 1395 (1953). The concept of territoriality has been introduced here to show only that the due process clause applies its protection, at minimum, to every individual physically present in the United States. This inuch the Supreine Court has acknowledged. Therefore, an illegal alien comes under the protection of that clause. The question of how far beyond the borders of the country and in what circumstances the clause will extend its protection to citizens and aliens will be left to other authors.

47. The greatest difference between expulsion and exclusion cases is evident prior to 1952. The Immigration and Nationality Act of 1952, 8 U.S.C. $\S \S 1-1557$ (1970), 
that an ahen who is present in the country has more of a right to due process during deportation than an alien who is merely "at the gates" seeking entry into the country. For example, the Supreme Court has stated:

It is true that aliens who have once passed through our gates, even illegally, may be expelled only after proceedings conforming to traditional standards of fairness encompassed in due process of law. ... But an alien on the threshold of initial entry stands on a different footing. "Whatever the procedure authorized by Congress is, it is due process as far as the alien denied entry is concerned." 48

A number of cases have also recognized that an alien physically present in the country has more of a right to request review of his deportation order than does one who is outside. The alien inside can request review either through a declaratory judgment action or by habeas corpus proceedings. The alien outside is limited to the latter action. ${ }^{49}$

The Supreme Court in Kwong Hai Chew v. Colding ${ }^{50}$ and in Nishimura Ekiu v. United States ${ }^{51}$ further exphicated the territorial nature of the due process clause. In the former case, the Court stated that an alien temporarily absent from the United States, while employed as a seaman on board a ship of American registry with a home port in the United States, was constructively present here, for constitutional purposes. He was still entitled to the "status of a continuous resident physically present in the United States." ${ }^{\text {2 }}$ Conversely, in Nishimura Ekiu the Court argued for constructive absence in a case where an immigration official was required by regulation to board a vessel to

reduced the difference in treatment between the two types of cases by allowing full due process of law in both.

48. Shaughnessy v. United States ex rel. Mezei, 345 U.S. 206, 212 (1953). See also Brownell v. Tom We Shung, 352 U.S. 180, 182-83 n.1 (1956); Kwong Hai Chew v. Colding, 344 U.S. 590, 596 (1953); Knauff v. Shaugnessy, 338 U.S. 537, 549 (1949); The Japanese Inumigrant Case, 189 U.S. 86, 98-99 (1903); Paktorovics v. Muff, 260 F.2d 610, 614 (2d Cir. 1958); GoRDON \& ROSENFIELD, supra note $23, \S 8.90$.

Soine cases, however, would challenge the proposition that aliens have inore extensive rights in expulsion cases than in exclusion cases. Estrada v. Ahrens, 296 F.2d 690, 692 (5th Cir. 1961), and Mezei v. Shaughnessy, 195 F.2d 964, 967-68 (2d Cir. 1952), rev'd, 345 U.S. 206 (1953), called for equal treatment of ahens physically present in the country and those who were either "at the gates" with a vahid visa or who had been residents of the United States but had temporarily left. The force of these decisions is not sufficient to overwhelm the line of cases that support the distinction between expulsion and exclusion. The Suprene Court cases that recognize a distimction are nuch clearer and more direct than the cases cited in Estrada or Mezei.

49. Lem Moon Sing v. United States, 158 U.S. 538, 547-48 (1895). The idea was not full elaborated in this case, but it is clearly implied by the reasoning. See also Shaughnessy v. Pedreiro, 349 U.S. 48, 51-52 (1955); Nishinuura Ekiu v. United States, 142 U.S. 651,652 (1892).

50. 344 U.S. 590 (1953).

51. 142 U.S. 651 (1892).

52. 344 U.S. at 600 . 
examine immigrants, but found it impractical to do so because of the delay and inconvenience involved. The Court stated that the official could "remove and detain the individuals on shore without such removal being considered a landing." 53

Thus, it appears that physical presence within the United States, except in rare instances, endows an individual with certain rights. The word "person" as used in the fifth and fourteenth amendments should be taken to mean literally every human being physically present within the borders of the United States. All aliens-those legally present and those illegally present-are entitled to due process of law. Under this reasoning, the federal court decisions in Arteaga v. Allen, ${ }^{54}$ Prassinos v. District Director of Immigration and Naturalization Service, ${ }^{55}$ Martinez v. Fox Valley Bus Lines, ${ }^{50}$ and Williams v. Williams ${ }^{57}$ which recognized an illegal alien's right to sue as an integral part of due process are clearly correct.

Several other considerations would lend additional support to this conclusion. To deprive an alien of this right because of a violation of the immigration laws would not only deny him due process of law but would also impose upon him a severe penalty in addition to those actually prescribed by the Immigration and Nationality Act. ${ }^{58}$ It would also, as Williams pointed out, violate the equal protection clause of the fourteenth amendnent since an "exclusion froin the court on this ground would discriminate without 'compelling' reason to do so against persons who violate this particular immigration law, as distinguished from persons who violate any other law." ${ }^{2}$ Such a denial would conflict with the principle, long-established by the Suprene Court, that a "person does not becoine an outlaw and lose all rights by doing an illegal act." ${ }^{\text {I }}$ It would also subject the alien to the responsibilities of

53. 142 U.S. at 662 . See also Shaughnessy v. United States ex rel. Mezei, 345 U.S. 206, 213-15 (1953). Sigfried Hesse notes that in the early immigration cases the Supreme Court distinguished between aliens who had been present in the country for a very short time and those who had been present for several years. He argues for the proposition that aliens who have becone firmly established within our society cannot bo deported for reasons that arose after their arrival here. Hesse, Permanent Resident Aliens, 69 YALE L.J. 262, 290-95 (1959). However, he does not argue that a long stay is necessary for the alien to have a right to due process.

54. 99 F.2d 509, 510 (5th Cir. 1938).

55. 193 F. Supp. 416 (N.D. Ohio), aff'd, 289 F.2d 490 (6th Cir. 1960), cert. denied, 366 U.S. 966 (1961). It should be noted that in this case, the court acknowledged the alien's right to sue, but, as will be discussed below, mistakenly assumed that this right could be entirely subordinated to the authority of the Immigration Service.

56. 17 F. Supp. 576 (N.D. Ill. 1936).

57. 328 F. Supp. 1380 (D.V.I. 1971).

58. See note 184 infra.

59. 328 F. Supp. at 1383.

60. National Bank \& Loan Co. v. Petrie, 189 U.S. 423, 425 (1902). 
domicile in this country, obedience to the laws of the United States and liability to suit for any civil wrongs committed against legal aliens or citizens, ${ }^{61}$ while denying him a chief benefit of such domicile-access to the courts. ${ }^{62}$

There is then good reason and authority to conclude that an alien illegally present in the United States possesses a right to sue in the courts of the various states. Although his illegal status subjects him to deportation and prosecution for violation of the immigration laws, it does not strip him of the rights granted by the due process clauses of the Constitution to every person within the nation's borders.

\section{B. Enforcing the Right}

As discussed above, an illegal alien has a right to sue guaranteed by both the fifth and fourteenth amendments to the Constitution. Sucl a right, to quote Justice Harlan, "must be enforced in the courts both of the nation and of the state." this right and is sustained in this refusal by the state appellate courts, an alien prejudiced thereby can file a suit against the trial judge under section 1983 of title 42 of the United States Code, and seek equitable relief. That relief may take the form of a writ of mandamus compelling the court to liear the case or an injuction preventing the court from dismissing the suit on the basis of illegal allienage.

Section 1983, a federal civil rights statute, provides:

Every person who, under color of any statute, ordinance, regulation, custom, or usage, of any State or Territory, subjects, br causes to be subjected, any citizen of the United States or other person

61. An alien is subject to suit in any jurisdiction where he is found. Brunette Machine Works v. Kockum Indus., 406 U.S. 706, 709 (1972).

62. This last result would be inconsistent with the line of Supreme Court decisions which have recngnized an interdependent relationship between an alien's domiciliary duties and his rights. "Every citizen or subject of another country while domiciled here is within the allegiance and protection and consequently subject to the jurisdiction of the United States." United States v. Wong Kim Ark, 169 U.S. 649, 693 (1898). "By general international law, foreigners who have become domiciled in a country other than their own acquire rights and must discharge duties in many respects the same as possessed by and impressed upon the citizens of that country ..." Lau Ow Bew v. United States, 144 U.S. 47, 61-62 (1892). "Every foreigner born residing in a country owes to that country allegiance and obedience to its laws so long as he remains in it, as a duty upon him by the mere fact of his residence and that temporary protection which he enjoys . . . " Carlisle v. United States, 83 U.S. 147, 155 (1872).

The concept of counterbalancing rights and liabilities as used here must not be overemphasized. Though the Supreme Court saw merit in the idea when considering whether aliens should have some basic rights to balance the duties imposed on them, it is highly unlikely that the Court would hold that an illegal alien must have the full complement of rights to which a legal alien is entitled before any duties can be imposed on him. It appears that the court is arguing for a substantially fair balance.

63. Gibson v. Mississippi, 162 U.S. 565, 591 (1896). 
within the jurisdiction thereof to the deprivation of any rights, privileges, or immunities secured by the Constitution and laws, shall be liable to the party injured in an action at law, suit in equity, or other proper proceeding for redress. ${ }^{64}$

There can be little doubt that section 1983 applies to the situation under discussion. First, it has been shown that an illegal alien qualifies as a "person within the jurisdiction [of the United States]" and that access to the courts of the land is a right "secured by the Constitution," by way of the due process clause. ${ }^{65}$ Second, it is generally acknowledged that official actions by a judge in court are actions "under color of state law." For example, the Supreme Court in Shelly v. Kraemer"0 has held that "in construing the terms of the Fourteentli Amendment differences have from time to time been expressed as to whether particular types of state action may be said to offend the Amendment's prohibitory provisions, it lias never been suggested that state court action is immunized from the operation of these provisions simply because the act is that of the judicial brancli of the state government." This opinion, reaffirmed more recently in Cooper $v$. Aaron, ${ }^{68}$ shows that judicial acts are indeed actions "under color of state law."

An objection might be raised against allowing an illegal alien to obtain equitable relief under section 1983 from a wrongful dismissal: the argument would be that the policy of judicial immunity prohibits the application of section 1983 to official judicial action. Sucli a theory would draw support froin comments in federal cases such as Thompson $v$. Baker. ${ }^{69}$ In that case the plaintiff claimed that a state court had improperly ordered the garnishment of his wages without requiring a formal filing of evidence by the creditor and without prior notice to him. He filed a suit against the state court under section 1983 seeking an injunction of the garnishment and monetary damages. The federal court held that judicial inımunity barred suits against the official acts of state courts and disimissed the plaintiff's suit. The Supreme Court gave some approval to this result by commenting in Pierson v. Ray ${ }^{70}$ that section 1983 did not abolish judicial immunity.

64. 42 U.S.C. $\$ 1983$ (1970) (emphasis added).

65. See text accompanying notes 36-62 supra.

66. 334 U.S. 1 (1947).

67. Id. at 18 (1947). In this case the Court said that there was an especially well-established tradition that judicial action was to be regarded as tate action when a court denied a person due process of law. Although these cases usually involved criminal prosecution, there is little reason for not applying them to the situation of an alien deprived of due process in the form of his right to sue.

68. 358 U.S. 1, 16-17 (1958).

69. 133 F. Supp. 247 (W.D. Ark. 1955). See also Sarelas v. Sheehan, 326 F.2d 490, 491 (7th Cir. 1963); Larson v. Gibson, 267 F.2d 386, 387 (9th Cir. 1959).

70. 386 U.S. 547,555 (1967). 
Although judicial immunity was applied to bar relief in Thompson v. Baker, however, that immunity would not prevent an illegal alien from securing equitable relief when his suit had been dismissed in state court. In the Thompson v. Baker situation, the plaintiffs were not only seeking injunctive relief but were also asking for money damages. That was the critical factor; the case took on the appearance of a common law tort action. In such a case the policy of judicial immunity is firmly entrenched. Had the plaintiff limited his request to injunctive relief, recent federal cases indicate that judicial immunity would not have barred that relief. ${ }^{71}$ The only situation in which courts have refused to allow injunctive relief, by itself, have been where the plaintiff sought to have the federal court interfere with an on-going case in state court. ${ }^{72}$ Where a suit by an illegal alien has been dismissed, there is no on-going litigation. Therefore, where a state court refuses to entertain a suit by an illegal alien solely on the ground of his illegal status, he can bring an action against the state court judge in federal court, provided he seeks only an imjunction against dismissal or a writ of mandamus to require the court to entertain the suit. He should not ask for money damages. ${ }^{73}$

\section{II}

\section{FEDERAL Court}

In contrast to the state courts, the federal courts have almost uniformly recognized the right of an alien to bring a civil suit despite his unlawful presence in the country. Martinez v. Fox Valley Bus Line ${ }^{74}$

71. See United States v. McLeod, 385 F.2d 734, 738 n.3 (5th Cir. 1967); United States v. Wood, 295 F.2d 772 (5th Cir. 1961); Stambler v. Dillon, 288 F. Supp. 646, 649 (S.D.N.Y. 1968); United States v. Clark, 249 F. Supp. 720, 727 (S.D. Ala. 1965). See also Conover v. Montemurro, 477 F.2d 1073, 1082 (3d Cir. 1973); Littleton v. Berbling, 468 F.2d 389, 404-08 (7th Cir. 1972); Bauers v. Heisel, 361 F.2d 581 (3d Cir. 1966); Bramlett v. Peterson, 307 F. Supp. 1311 (M.D. Fla. 1969); Phillips v. Cole, 298 F. Supp. 1049 (N.D. Miss. 1968). Littleton and Conover rely heavily on Lucus v. Forty-fourth General Assembly, 377 U.S. 713 (1964), Cooper v. Aaron, 358 U.S. 1 (1959), and Sterling v. Constantin, 287 U.S. 378 (1932), which do not deal specifically with judicial immunity. But cf. Bethea v. Reid, 445 F.2d 1163 (3d Cir. 1971); Arensman v. Brown, 430 F.2d 190, 194 (7th Cir. 1970); Cooper v. Hutchinson, 184 F.2d 119 (3d Cir. 1950).

72. Compare Stevens v. Frick, 372 F.2d 378, 380-81 (2d Cir. 1967), with Littleton v. Berbling, 468 F.2d 389, 408 (7th Cir. 1972), and Goss v. Illinois, 312 F.2d 257, 259 (7th Cir. 1963).

73. Pierre v. Jordan, 333 F.2d 951, 958 (9th Cir. 1964), and Goss v. Illinois, 312 F.2d 257 (7th Cir. 1963), hold that the main object of a suit under 42 U.S.C. $\$ 1983$ must be to vindicate the plaintiff's civil rights. Hence the suit cannot be combined with another cause of action. Further, if an objection were raised that $\$ \$ 1981$ and 1983 do not provide a specific remedy, this objection should be easily overcome by Sullivan v. Little Hunting Park, Inc., 396 U.S. 229 (1969), which held that the "existence of a statutory right implies the existence of all necessary and important remedies." Id. at 239.

74. 17 F. Supp. 576 (N.D. Ill. 1936). 
involved an alien's personal imjury action against a bus company. The defendant contended that because the plaintiff had entered the country illegally he was "not entitled to bring any suit in courts of the Umited States." 75 The trial court rejected this defense and held that although illegally present, the alien was covered by both the fourteenth amendment and section 1981 and therefore had standing to sue. ${ }^{78}$ Williams v. Williams ${ }^{77}$ involved an alien who had lawfully entered but had overstayed his visa and, therefore, was unlawfully present in the territory. Reasoning that to deny access to the court because of a violation of an immigration law would deny due process, unfairly increase the punishment prescribed for the violation, and unreasonably discriminate between violators of this law and violators of any other law, the court held that the alien had a right to sue for divorce. ${ }^{78}$ Several other cases including Guerra v. Manchester Terminal Corporation, ${ }^{78}$ Roberto v. Hartford Fire Insurance Company, ${ }^{80}$ and Arteaga v. Allen ${ }^{81}$ indirectly recognized that a person's status as an illegal alien does not strip him of legal standing before a court. Admittedly, there are few cases specifically dealing with the judicial status of an alien unlawfully in this country; those cases that do, however, indicate a definite policy of recognizing the alien's right to sue.

\section{A. The Immigration Service}

Despite the explicit recognition of an illegal alien's right to sue in the federl courts, such an alien is not always able to exercise that right effectively. Several courts have adopted an attitude so deferential toward the authority of I.N.S. to control immigration that they have, in effect, made the right to sue dependent upon the discretion of immigration officials. In Prassinos v. District Director of the Immigration and Naturalization Service, ${ }^{82}$ Petros Prassinos, after legally entering the country for a brief visit, did not depart by the appointed day. Seven inonths later he was apprehended in the vicinity of Chicago when his

75. Id. at 577 .

76. Id.

77. 328 F. Supp. 1380 (D.V.I. 1971).

78. Id. at 1383 .

79. 350 F. Supp. 529,536 (S.D. Tex. 1972).

80. 177 F.2d 811, 813 (7th Cir. 1949).

81. 99 F.2d 509 (5th Cir. 1938). This action was not brought by the illegal alien himself; rather, it was brought by the alien's mother, who alleged that the defendant had caused her son's wrongful death. The court allowed the suit, reasoning that even "if it be assumed that her son's entry was illegal, it could not possibly follow that by such illegal entry he was made an outlaw, whose death anyone could compass without legal accountability." Id. at 510 . From this it can be implied that had the alien survived he would have been allowed to sue for any injuries.

82. 193 F. Supp. 416 (N.D. Ohio 1960), aff'd, 289 F.2d 490 (6th Cir. 1961), cert. denied, 366 U.S. 966 (1961). 
presence came to the attention of the Immigration Service after he had been injured on a job there. After a hearing he was found to be deportable; he was also found to be eligible for voluntary departure and was given the opportunity to so depart. ${ }^{83}$ Subsequent to the hearing but before the alien could depart, he was prosecuted, convicted, and sentenced to six months imprisonment for willfully overstaying his allotted time in the United States. After serving two months of his sentence, Prassinos was offered the opportunity of a parole for the purpose of leaving the country. Again he was granted voluntary departure on the condition that he leave the country. He felt compelled to decline these offers, however, simce he needed time to follow up a claim against his Chicago employer. Thus, he reniained in prison. When he was later released, Prassinos again sought to pursue his claim. The Immigration Service ordered his deportation but stayed it until his claim could be settled. The Service, however, would not grant Prassmos voluntary departure even though he liad been considered qualified on two previous occasions. (Like the deportation order, implementation of voluntary departure could liave been stayed pending the outcome of the claim.) After successfully settling his claim before the Illinois Industrial Commission, Prassimos surrendered himself to the Immigration Service for deportation. At the same time he sought a declaratory judgment in the district court agaimst the deportation order arguing, among other grounds, that he was entitled to voluntary departure. The district court rejected his arguments and refused to set aside the order of deportation. The court commented that in its opinion the Immigration Service not only had the power and authority to set conditions on a grant of voluntary departure which would put an alien in the "unfortunate" dilemma ${ }^{84}$ of choosing between giving up a valuable finan-

83. Id. at 418. Voluntary departure is allowed under 8 U.S.C. $\$ 1254$ (e) (1970).

84. Id. at 420-1. The dilemma in which Prassinos found himself was a different one. There is a great difference between voluntary departure and deportation. Voluntary departure is clearly preferable, a fact which the Conrt of Appeals for the Third Circuit recognized in Strantzalis v. I.N.S., 465 F.2d 1016, 1017 (3d Cir. 1972).

Voluntary departure is a form of discretionary relief that the Immigration Service can grant to a deportable alien whereby he is allowed to leave the country at his own expense if he is judged to be eligible. No deportation order is issued, and no sanctions are imposed on the alien.

The burdens of deportation are quite heavy. In addition to being forced to leave the country the alien is subject to prosecntion for unlawful entry, which carries a fine of $\$ 500$ and imprisonment for up to six months. 8 U.S.C. $\$ \S 1325,2199,1306$ (1970). Such prosecntion often does occur. See, e.g., the alien's treatment in Prassinos. Bnt the more important concern is the effect of deportation on an alien's ability to return to the country. If an alien is ordered deported, he is barred from reentry into the United States unless he obtains special permission from the Attorney General to reapply for entry. Both the request to reapply and the reapplication itself can be deuied on discretionary grounds. 8 U.S.C. $\$ \S 1101(\mathrm{~g}), 1182(\mathrm{a})(16)-(17)(1970)$. The alien loses any advantages for entry that lie may have had due to his status as parent or spouse 
cial claim or foregoing voluntary departure (thus, accepting the burdens of deportation), but that the Service also had the power to deport an alien immediately after his release from prison without affording him the opportunity of pursuing his claim. Thus, in the court's opinion, Prassinos had been most kindly treated by the Immigration Service. ${ }^{85}$ The Court of Appeals for the Fifth Circuit affirmed the holding in this case and accepted the district court's reasoning.

In effect the court was saying that the alien's right to sue was clearly subordinate to the authority of Congress to control immigration (through the agency of the I.N.S.) and that it need not be given more than passing attention. ${ }^{86}$ The Immigration Service, using its discretion, could deport an alien without granting him an opportunity to pursue a valid claim, ${ }^{87}$ or it could "chill" the effective exercise of the right by placing the alien in the dilemma of giving up either his valid claim or

of an American citizen. If he should reenter without permission, the criminal sanctions are harsher for him than for an alien who unlawfully enters but had no prior deportation: the offense is a felony punishable by two years in prison and a fine of $\$ 1,000$, rather than a misdemeanor punishable by six months in prison and a fine of $\$ 500$. 8 U.S.C. $\$ \S 1325,1326$ (1970). The government's case is also much easier to prove against a previously deported alien for all that is required is "presence." Section 1326 prohibits being "found" in the country after having been deported. See Pena-Cabanillas v. United States, 394 F.2d 785 (9th Cir. 1968). Yet if he accepts voluntary departure he in effect is giving up his legal claim. Once the alien is outside the country it is difficult for him, practically or legally, to maintain a suit inside this country. Cf. GoRDoN \& ROSENFIELD, supra note $23, \S 1.37$.

85. 193 F. Supp. at 420.

86. The question may be raised whether the case can be explained by the dilatory nature of the alien's action. He had, after all, failed to report to the I.N.S. for seven months. In response to this question it can be said that the court did not concern itself with the question whether the alien was simply trying to delay eventual deportation. The court did not decide that the claim for injury was a sham. This would have been difficult since the Illinois Industrial Commission eventually determined that the claim was valid. In fact, the court appears to acknowledge that the claim was probably valid. "We agree that it is unfortunate that circumstances were such that to voluntarily deport might have deprived him of an equitable financial settlement of his claim for injury on the job." 193 F. Supp. at 420 . Whether or not the suit was part of a dilatory scheme, the court would subject the alien's right to sue to the discretion of the Immigration Service.

87. It is important to note that authority of Congress to control immigration is not to be treated lightly. Therefore, it should be limited by the alien's right to sue only where there is a valid, non-collusive cause of a action, as where the alien is honestly seeking to recover for a wrong done and does not have as lis major purpose simply prolonging lis stay in this country. Without a requirement of "good faith" on the part of the alien, the right can be absued and may seriously hamper the Immigration Service in the performance of its duty. (Some techniques for determining when an alien's claim is made in good faith are suggested in the text below.) It is also important to note that the right to sue will require a stay of deportation or an extension of the voluntary departure date only so long as the alien's presence is required for adequate pursuit of his cause of action. It does not require delay until completion of the trial in every situation. There may be times when, due to a crowded court calendar, the alien will simply be waiting for his trial to come up. 
the benefit to which he had been considered entitled. ${ }^{88}$

To be sure, all constitutional rights are subject to limitations. The right to sue, however, has been subject to very few restraints, since its free exercise is essential to our system of law. ${ }^{89}$ It is not consistent with this tradition to make the right dependent on the broad discretion of an individual. Neither the fact that there are few cases similar to Prassinos nor the fact that I.N.S. claims its "usual policy" to be the extension of the voluntary departure date in order to allow an alien to conclude pending litigation ${ }^{00}$ offers a complete solution to the problem. If an alien's exercise of this right depends upon a favorable discretionary decision by a government official, or if it can be "chilled" by retaliatory treatment, ${ }^{91}$ then it can hardly be called a right at all. ${ }^{92}$

That the court in Prassinos deferred to the discretionary actions of the I.N.S. is understandable. This is the customary procedure when dealing with the ordinary immigration case. ${ }^{93}$ The Supreine Court has clearly acknowledged that the exercise by I.N.S. of its discretion to grant or deny relief in deportation cases is to be given wide latitude

88. Although voluntary departure is a discretionary form of relief, in this case the alien had twice been granted the opportunity of voluntary departure. It is clear that the crucial factor in the eventual denial was the alien's insistence on pursuing lis claim. The court, therefore, allowed I.N.S. to treat the alien harshly solely because the alien had exercised his right to sue.

89. See text accompanying notes $24-26,31-32$ supra.

90. See Gordon \& Rosenfield, supra note 23 , $\$ 5.16(a)$, at 5-121. See also Adame v. I.N.S., 349 F. Supp. 313, 315 (N.D. Ill. 1972).

Despite official statements to the contrary, I.N.S. has several practical policies that would militate against granting additional time nor illegal alien is to maintain civil suits. One of the Service's nain objectives has been to remove all deportable aliens from the country in the shortest time possible. (1973 I.N.S. Ann. Rpt. 9) To achieve this objective, inmigration officials have been authorized to deny discretionary relief whenever an alien's activity appears dilatory. See GoRDon \& Rosenfield, supra note 23, § 8.9Af, at 8-70. See also Foti v. I.N.S., 375 U.S. 217, 225-26 (1963); Braude v. Wirtz, 350 F.2d 702, 705 (9th Cir. 1965); In re Paduano, 13 I. \& N. Dec. 658, 660 (1971); GoRDON \& ROSENFIELD, supra note 23, \& 8.15c, at 8-102. Another policy has been to deny discretionary relief to an alien who has had prior immigration violations. See GoRDoN \& Rosenfield, supra note $23, \$ 8.15 \mathrm{c}$, at $8-102$ and 103 . Many illegal aliens have a record of prior entry violations. Cf. Severo, Flight of the Wetbacks: The Hunted are Also Hunters, N.Y. Times, March 10, 1974, at 79 (Magazine). In view of these pohicies, it is unlikely that nuany illegal aliens who come before an immigration official seeking to delay deportation or voluntary departure will receive a favorable response. This is exemplified in Prassinos, where the alien was denied an extension of voluntary departure although he had a valid claim.

91. The retaliatory treatment referred to is evident in Prassinos where, although the ahen had twice becn considered eligible for voluntary departure and had, in fact been twice granted it, he was denied voluntary departure after he insisted on pursuing his suit. 193 F. Supp. 416, 420.

92. Limitations on this right are discussed in the text accompanying notes 185187 infra.

93. Rassano v. I.N.S., 492 F.2d 220, 225 (7th Cir. 1974). 
by the courts. ${ }^{94}$ Also, the court may feel compelled to defer by the formidable lists of cases holding that Congress has the power to control entry into the country and to set conditions for an alien's stay. ${ }^{95}$ 'These cases contain sweeping language: the control of immigration is said to be "committed exclusively to Congress," "so "subject to the plenary power of Congress," "necessarily very broad touching as it does basic aspects of national sovereignty," political branches of the government as to be largely immune from judicial inquiry or interference." 99

Nevertheless, as will be shown below, the court in Prassinos should not have held that immigration officials could block exercise of the right to sue. Authority to control entry into the country may be essential to the nation's well-being, but it is not so important that it can demand deference from the courts in all circumstances. The Supreme Court has recognized that decisions by the I.N.S., even those considered discretionary, are subject to review by the federal courts. ${ }^{100}$ In

94. Jay v. Boyd, 351 U.S. 345, 354, 357 (1956). See also Kleindienst v. Mandel, 408 U.S. 753 (1972); Bugajewitz v. Adams, 228 U.S. 585, 591 (1912); Ferreira v. Shaughnessy, 241 F.2d 617, 618, 620 (2d Cir. 1957); Gordon \& Rosenfield, supra note $23, \S 7.16$.

95. See Galvan v. Press, 347 U.S. 522, 530 (1953); Carlson v. Landon, 342 U.S. 524, 534 (1951); United States v. Curtis-Wright Export Corp., 299 U.S. 304, 318 (1936); Lloyd Sabaudo Societa Anonima per Azioni v. Elting, 287 U.S. 329 (1932); Ng Fung Ho v. White, 259 U.S. 276, 280 (1922); Zakonaite v. Wolf, 226 U.S. 272 (1912); United States v. Sing Tuck, 194 U.S. 161 (1904); The Japanese Immigrant Case, 189 U.S. 86 (1903); Turner v. Williams, 194 U.S. 279, 290 (1903); Chm Bak Kan v. Unitcd States, 186 U.S. 193 (1902); Fok Yung Yo v. United States, 185 U.S. 296 (1902); Wong Wing v. United States, 163 U.S. 228 (1896); Len1 Moon Sing v. United States, 158 U.S. 538, 541-42 (1895); Fong Yue Timg v. United States, 149 U.S. 698, 707 (1893); Nishimura Ekiu v. United States, 142 U.S. 651,659 (1891).

Hesse, supra note 53, argues that congressional power to deport a legal alien ceases when the alien has been a resident for a long time if the basis for that deportation arose after his entry into this country. To support his argument he very thoroughly examines the pre-1917 deportation cases and shows that the later Court opinions have misunderstood their import. The Supreme Court, however, has cone to hold that the congressional authority over aliens is quite broad and not subject to the time limits which Hesse suggests.

96. Lloyd Sabaudo Societa Anonima per Azioni v. Elting, 287 U.S. 329, 334 (1932).

97. Carlson v. Landon, 342 U.S. 524, 534 (1951).

98. Galvan v. Press, 347 U.S. 522, 530 (1953).

99. Harisiades v. Shaughnessy, 342 U.S. 580, 589 (1952). In fact, congressional authority to control entry of aliens is so well established that Martinez v. Fox Valley Bus Lines, 17 F. Supp. 576, 577 (N.D. Ill. 1936), and Janusis v. Long, 188 N.E. 228, 230 (Mass. 1933), implicitly conceded that Congress could possibly have deprived an illegal alien of the right to sue, even though this concession was tantamount to saying that Congress could pass unconstitutional legislation. The courts in these cases had a reason to emphasize congressional authority over immigration; it made their decisions easier. It was sufficient for the purpose of settling the cases before then to say that if Congress had not stripped the alien of this right, it was not for the courts to do so.

100. See text accompanying notes 106, 115-26, 128-32, 153-63 infra. 
Prassinos the court could have accommodated both the authority of Congress and the rights of the alien. ${ }^{101}$

\section{The Tradition of Judicial Review}

Notwithstanding the sweeping statements quoted above, the Supreme Court has long held that decisions in deportation cases are subject to judicial review. ${ }^{102}$ The same courts which described the deportation power in such sweeping terms recognized that the exercise of that power was not to be free from judicial scrutiny. ${ }^{103}$ Prior to

101. See Hong v. Agency for International Development, 470 F.2d 507 (9th Cir. 1972). In Hong the court admitted the validity of the deportation order and the autliority of I.N.S. to determine deportability, yet it granted the alien a temporary restraining order prohibiting deportation and allowing him time to pursue lis contract claim. Thus, the Hong court did not imterfere with deference in determinations of deportability, but it did keep the policy of deference in that area from vitiating the alien's constitutional rights by refusing to allow the alien's deportation until the had had a chance to bring suit. In contrast, the court in Prassinos was quite willing to allow the alieu's right to be completely subordinated to the authority of I.N.S. and to allow I.N.S. to deport the alien without an opportunity to sue, if it so wished.

The breach of contract that was Hong's cause of action immediately resulted in his becoming deportable, but this fact should not affect the general applicability of the holding in the case. The court leeld that the two issues of breach of contract and deportability should be treated separately, since "I.N.S. had no jurisdiction to adjudicate the legal issues raised in Hong's action against A.I.D." Id. at 508.

The alien in the Hong case did not seek to reinstate the voluntary departure that he liad been offered. He was satisfied with obtaining a stay of deportation. It is possible however that had he requested the reinstatement, it too would lave been granted if the circunstances were such that otherwise there would be a "clilling" effect on his right to sue; for the court was careful to prevent an alien's claim against A.I.D. from being affected by the authority of I.N.S. to control deportation. Admittedly, this result is speculative. But it is not unusual for a court to compel the granting of discretionary relief over the objection of the Immigration Service when the court feels that a clear injustice would otherwise occur. See, e.g., Rassano v. I.N.S., 492 F.2d 220 (7th Cir. 1974).

102. Giova v. Rosenberg, 379 U.S. 18 (1964); Foti v. I.N.S., 375 U.S. 217, 221 (1963); Umited States ex rel. Hintopoulos v. Slaughnessy, 353 U.S. 72, 77 (1957); Brownell v. Tom We Shung, 352 U.S. 180, 182 (1956); Shaughnessy v. Pedreiro, 349 U.S. 48, 50, 51 (1955); Yanish v. Barber, 73 S. Ct. 1105, 1108 (1953); Jordan v. DeGeorge, 341 U.S. 223, 231 (1951); Bridges v. Wixon, 326 U.S. 135, 156 (1945); Kessler v. Strecker, 307 U.S. 22, 34 (1939); Vajtauer v. Comm'r of Immigration, 273 U.S. 103, 106 (1927); Bilokunsky v. Tod, 263 U.S. 149, 153, 157 (1923); Gonzalez v. Williams, 192 U.S. 1, 15 (1904); Lau Ow Bew v. United States, 144 U.S. 47, 59 (1892). See also Cheng Fan Kwok v. I.N.S., 392 U.S. 206, 216 (1968); Fong Haw Tan v. Plielan, 333 U.S. 6, 10 (1948); United States ex rel. Tisi v. Tod, 264 U.S. 131, 133-34 (1924).

103. Carlson v. Landon, 342 U.S. 524, 539, 543 (1951); Lloyd Sabaudo Societa Anonima Per Azioni v. Elting, 287 U.S. 329, 335 (1932); Ng Fung Ho v. White, 259 U.S. 276, 279 (1922); Turner v. Williains, 194 U.S. 279, 291 (1903); Wong Wing v. United States, 163 U.S. 218, 236-38 (1896); Lem Moon Sing v. United States, 158 U.S. 538, 545-46 (1895). See also Galvan v. Press, 347 U.S. 522, 531 (1953); United States ex rel. Eichenlaub v. Shaughnessy, 338 U.S. 521, 529 (1950); Gegiow v. Uhl, 239 U.S. 3, 9 (1915); Chm Bak Kan v. United States, 186 U.S. 193, 200 (1901); Fong Yue Ging v. United States, 149 U.S. 698, 713 (1892). 
1955 , there was some question whether review could be secured only through habeas corpus proceedings, or whether it could also be secured through a declaratory judgment action. ${ }^{104}$ However, there is no question that judicial review of deportation orders has always been available in soine form. ${ }^{105}$ Similarly, "discretionary" determinations by the Immigration Service have been subject to judicial review. ${ }^{106}$

\section{The Guidelines for Judicial Review}

The precise limits on discretion and the standard of review, however, are far from clear. Very few Supreme Court decisions dealing with the limits on discretion have attempted to set definite guidehines for review; those that have tried have not been completely successful. The resulting case law on review of discretion is disjointed and often contradictory. ${ }^{107}$ Nevertheless, through the confusion the following three principles can be discerned.

104. Shaughnessy v. Pedreiro, 349 U.S. 48, 49-51 (1955), and Brownell v. Tom We Shung, 352 U.S. 180, 184-85 (1956), contain evidence of this controversy.

One case, Heikkila v. Barber, 345 U.S. 229 (1953), held that deportation decisions could not be reviewed by way of declaratory judgment and that review through habeas corpus was limited to a narrow enforcement of procedural due process. No substantive matters could be reviewed. This case has not been officially overruled, but its impact has been greatly reduced. The Brownell and Pedreiro cases which follow within three years of Heikkila limited its application to cases arising under the 1917 Immigration Act, even though the 1952 act was, according to the dissent in Pedreiro, "a re-enactment, almost verbatim" of the 1917 Act. 349 U.S. at 54. It is important to noto that contrary to the implication in Heikkila, the Supreme Court has not taken a "hands off" attitude toward immigration cases, and that Heikkila misinterpreted the cases that preceded it. The long line of cases cited above in footnotes 102 and 103 very clearly recognize that administrative determinations made by I.N.S. are not final, that courts have a duty to review the deportation decision, and that the review is not to be limited merely to looking for compliance with procedural due process.

A more thorough analysis of the Heikkila decision is given in K. DAvIs, ADMINIstrative LaW Treatise (1958) $\$ 28.10$, at 47-55 [hereinafter cited as Davis]. Professor Davis concludes that Heikkila was an aberration from a line of cases that allowed increasingly broader review in deportation cases.

105. Justice Brewer's concurring opinion in Turner $v$. Williams exemplifies the sentiment that is found in almost every Supreme Court decision on the matter: "I do not believe it within the power of Congress to give its ministerial officers a final adjudication of the right to liberty or to oust the courts from the duty of inquiry respecting both law and facts." 194 U.S. 279, 295 (1903).

106. Cf. Cheng Fan Kwok v. I.N.S., 392 U.S. 206, 210-13 (1968); Foti v. I.N.S., 375 U.S. 217, 228-29 (1963); Dessalernos v. Savoretti, 356 U.S. 269 (1958); Yanish v. Barber, 73 S. Ct. 1105, 1108 (1953); Carison v. Landon, 342 U.S. 524, 539 (1952); Wong Wing Hang v. I.N.S., 360 F.2d 715, 717-18 (2d Cir. 1965); Gagliano v. I.N.S., 353 F.2d 922 (2d Cir. 1964); Wadman v. I.N.S., 329 F.2d 812 (9th Cir. 1964). See also S. Thompson, Development in the Law, 66 HARv. L. Rev. 643, 699-701 (1953).

107. This situation led Professor Davis to ocinment that "the opinions of the Supreme Court in recent decades are completely devoid of any formulation of principle concerming the Constitutional minimum for roview." Davis, supra note 104, § 28.19. Although Davis was addressing judicial review of all administrative decisions, the statc- 


\section{a. Review of fact determinations}

The Supreme Court allows a thorough review of fact determinations made in deportation proceedings. ${ }^{108}$ The present statute, passed in 1961, set forth the standard for judicial review in deportation proceedings. Findings of fact by the Attorney General (i.e., the Immigration Service) are to be conclusive "if supported by reasonable, substantive and probative evidence on the record considered as a whole." This has been interpreted to mean that the standard of review will be the "substantial evidence" test commonly applied in other contexts. The reviewing court will examime whether the finding is supported by substantial evidence. In Woodby v. Immigration and Naturalization Service ${ }^{111}$ the Supreme Court increased the extent and the thoroughness of the review under the "substantial evidence" standard in immigration cases. ${ }^{112}$ There the Court held that the government was under a heavy burden to prove its findings of fact. The evidence supporting those findings inust be "clear, unequivocal and convincmg."113 In implementing judicial review, therefore, the lower courts were to examine the facts carefully to see whether or not the findings comphed with the new, stricter criteria. ${ }^{114}$

The standard of review in proceedings for discretionary relief (as distinguished from general deportation proceedings) was set forth in Carlson v. Landon, ${ }^{115}$ where the Court remarked that a discretionary

ment is applicable to immigration cases in particular. The lower federal courts when dealing with immigration matters have occasionally made similar comments. Wong Wing Hang v. I.N.S., 360 F.2d 715, 718 (2d Cir. 1965); Alexiou v. McGrath, 101 F. Supp. 421, 424 (D.D.C. 1951).

108. Some consider the review allowed to be too thorough. For exanple, Justice Clark, dissenting in Woodby v. I.N.S., 385 U.S. 276, 370-71 (1966) comments that in the Woodby case as in earker cases prior to the 1961 amendment to the immigration statutes, the majority interpreted the immigration statutes in a more liberal manner than Congress had intended, allowed too broad a review of deportation proceeding, and thereby unnecessarily limited the authority of the Immigration Service.

109. 75 Stat. 651 (1961), 8 U.S.C. \$ 1105 (a) (4) (1964).

110. Woodby v. I.N.S., 385 U.S. 276, 282 (1966).

111. 385 U.S. 276 (1966).

112. For further discussion of how a heavier burden of proof increases the extent of review without affecting the standard of review see Cominent, Standard of Proof in Deportation Proceedings, 18 STAN. L. REv. 1237, 1239-40 (1966).

113. 385 U.S. 276, 286 (1966).

114. The dissent in Woodby indicated that the majority treated the fact determination too cursorily. 385 U.S. at 292 . For examples of review by the lower courts see Rasano v. I.N.S., 492 F.2d 220 (7th Cir. 1974); Buffalino v. I.N.S., 473 F.2d 728 (3d Cir. 1973); McConney v. I.N.S., 429 F.2d 626, 628 (2d Cir. 1970); Lavoie v. I.N.S., 418 F.2d 732 (9th Cir. 1969).

When, however, the crucial determination is the credibility of witnesses, the courts have deferred more to IN.S. findings. Cf. Kokkinis v. District Director of the I.N.S., 429 F.2d 978 (2d Cir. 1970); Espinoza Ojeda v. I.N.S., 419 F.2d 183 (9th Cir. 1969).

115. 342 U.S. 524 (1952). 
decision could be overturned if there were "no reasonable foundation for the decision." 116 This statement has been commonly interpreted as setting the same standard of review as in general deportation proceedings: the test for "substantial evidence."117 The Woodby opinion does not technically apply in proceedings for discretionary relief. ${ }^{118}$ In these situations the burden is on the alien to show his eligibility for relief and to show that the I.N.S. abused its discretion in refusing to grant the relief requested. Nevertheless, in cases involving discretionary relief the extent of review of fact determinations has been almost as thorough as that in general deportation situations. Perhaps influenced by the Supreme Court's own thorougl examination of the evidence in Carlson, ${ }^{119}$ or by the close scrutiny that is applied to fact determinations in deportation and denaturalization proceedings ${ }^{120}$ (which at least to a small degree are similar to discretionary decisions $^{121}$ ), or by the thorough review in earlier Supreme Court cases, ${ }^{122}$ the lower courts carefully examine the evidence supporting the Service's findings of fact. ${ }^{123}$

The most recent example is Rassano v. Immigration and Naturalization Service ${ }^{124}$ where the court reversed a demal of the alien's request for suspension of deportation. The I.N.S. had found that the alien was not a person of good moral character and therefore was not eligible for the relief requested. The court, commenting that it would not act as a "rubber stamp" for the Immigration Service's actions, ${ }^{125}$

116. Id. at 541 .

117. Wong Wing Hang v. I.N.S., 360 F.2d 715, 717 (2d Cir. 1965).

118. Rassano v. I.N.S., 492 F.2d 220, 223 (7th Cir. 1974).

119. In Carlson the court examined the actions by the alien and the damage involved and balanced them against the congressional intent to protect the nation from communists.

120. Woodby v. I.N.S., 385 U.S. 276, 285 (1966).

121. These proceedings all involve an individual determination by the inmigration official to pursue the defendant or to allow him to remain in the country.

122. Supreme Court cases until 1953 showed a gradual expansion of review culminating in Bridges v. Wixon, 326 U.S. 135 (1945). This trend came to a halt in Heikkila v. Barber, 345 U.S. 229 (1953). Heikkila has been limited by latcr opinions, loowever, e.g., Shaughnessy v. Pedreiro, 349 U.S. 48 (1955), and Brownell v. Tonı We Shung, 352 U.S. 180 (1956), and the trend lias not been completely and unequivocably reviewed. See Davis, supra note 104 , $\$ 28.10$.

123. Cf. Rassano v. I.N.S., 492 F.2d 220 (7th Cir. 1974); Khalil v. I.N.S., 457 F.2d 1276, 1277-79 (9th Cir. 1972); Gagliano v. I.N.S., 353 F.2d 927 (2d Cir. 1965); United States ex rel. Adel v. Shaughnessy, 183 F.2d 371, 372 (2d Cir. 1951); Alexiov v. McGrath, 101 F. Supp. 421, 424 (D.D.C. 1951). But cf. Wong Wing Hang v. I.N.S., 360 F.2d 715, 719 (2d Cir. 1965) (where the court does examine the evidence for the finding but is willing to give more leeway to the I.N.S. and is more reluctant to overturn the finding).

124. 492 F.2d 220 (7th Cir. 1974).

125. Id. at 227. 
closely examined the evidence on record, determined that the evidence did show good moral character, and reversed the order. ${ }^{126}$

The first guideline that can be discerned, therefore, leads away from broad deference to the I.N.S. By rigorous apphication of the "substantial evidence" test, the courts are to scrutinize carefully the evidentiary basis of fact determinations. At least to this limited extent, the courts are to strike a balance between the amount of discretion necessary for the I.N.S. effectively to perform its important function of controlling immigration and the degree of restriction on the I.N.S. that is necessary to protect the alien from mistreatment.

\section{b. Review of questions of law}

In addition to review of determinations of fact, a second restraimt on administrative discretion has long been recognized. Throughout its history, the Court has uniformly allowed rather broad judicial review whenever a question of law has been involved. Case after case has supported the proposition that interpreting the meaning of statutes is a judicial function. Some have done so directly: "rulings of the [immigration officer] on questions of law are without finality,"127 "[t] $]$ he courts are not forbidden by the statutes to consider whether the reasons when they are given agree with the requirement of the act."128 Other cases, like Fong Haw Tan v. Phelan, ${ }^{129}$ have done so implicitly by simply going through the process of statutory interpretation. As part of this process the Court has allowed redetermination of questions of fact which are intimately tied to questions of law. For example, the Court could determine whether an alien fell within the scope of the statute when it was properly interpreted, ${ }^{130}$ whether an action taken by the I.N.S. was permitted by the statute, ${ }^{131}$ or whether the statute

126. Id.

127. Crowell v. Benson, 285 U.S. 22, 45 (1932).

128. Gegiow v. Uhl, 239 U.S. 3, 9 (1915); accord, Crowell v. Benson, 285 U.S. 22, 45-46 (1932). See also United States ex rel. Eichenlaub v. Shaughnessy, 338 U.S. 521, 529 (1950); Fong Haw Tan v. Phelan, 333 U.S. 6, 9: (1948); Bridges v. Wixon, 326 U.S. 135, 149 (1945); Kessler v. Strecker, 307 U.S. 22, 30 (1939); Lloyd Sabaudo Societa Anonima per Azioni v. Elting, 287 U.S. 329, 335 (1932); Turner v. Williams, 194 U.S. 279, 295 (1904) (concurring opinion); Gonzales v. Williams, 192 U.S. 1, 15 (1903).

129. 333 U.S. 6, 9-10 (1948). See Foti v. I.N.S., 375 U.S. 217, 221 (1963); Shaughnessy v. Pedreiro, 349 U.S. 48, 51 (1955); Kwong Hai Chew v. Colding, 344 U.S. 590, 596 (1953); Jordan v. DeGeorge, 341 U.S. 223, 226-27 (1951); United States ex rel. Johnson v. Shaughnessy, 336 U.S. 806, 814 (1949); Wong Wing v. United States, 163 U.S. 228, 236-37 (1896); Lau Ow Bew v. United States, 144 U.S. 47, 59 (1892).

130. See Fong Haw Tan v. Phelan, 333 U.S. 6 (1948); Kessler v. Strecker, 307 U.S. 22 (1939); Gonzales v. Williams, 192 U.S. 1 (1903).

131. See Hintopoulos v. Shaughnessy, 353 U.S. 72, 77 (1957); Jay v. Boyd, 351 U.S. 345,353 (1956). 
required additional action by the I.N.S. ${ }^{132}$

The authority to review questions of law has supplemented the authority to review questions of fact and has given the courts even greater control over both the general deportation and the discretionary proceedings. On several occasions ${ }^{133}$ the Supreme Court has used this additional authority to achieve just results in situations where the "substantial evidence" test had been met and the Court would not otherwise have been able to overturn the decision. On these occasions the dissenting justices explicitly pointed out that the majority was going beyond the limited scope of the Court's authority to review, and that despite its disclaimers, the majority was "transfer[ring] to the courts control of executive discretion"134 and "justify[ing] capricious judicial intervention on behalf of the individual" ${ }^{355}$ in "no less than an attempt to circumvent the law itself." 136

Therefore, the second guideline for judicial review can be expressed as follows: a court can extensively review a discretionary decision if the abstract meaning of a statute or its application to the specific facts of a case are at issue.

\section{c. Review of constitutionality}

The third guideline is much broader than the preceding two. Indeed, the first two can be seen as derivatives of the third: a court may review a discertionary decision whenever it is claimed that a constitutional right has been violated, either directly or indirectly, by the decision. The Supreme Court has uniformly held that the Constitution is the supreme law of the land for all legislatures and the admimstrative agencies through which they work. ${ }^{137}$ Accordingly, in general depor-

132. See United States ex rel. Johnson v. Shaughnessy, 336 U.S. 806 (1949); Lloyd Sabaudo Societa Anonima per Asioni v. Elting, 287 U.S. 329, 335 (1932).

133. See United States ex rel. Accardi v. Shaughnessy, 347 U.S. 260, 268 (1954); United States ex rel. Johnson v. Shaughnessy, 336 U.S. 806, 814 (1949); Kessler v. Strecker, 307 U.S. 22, 34 (1939); Lloyd Sabudo Societa Anonina per Azioni v. Elting, 287 U.S. 329, 334, 338 (1932); cf. McGrath v. Kristensen, 340 U.S. 162, 169-81 (1950). See also the narrow interpretation recommended by the dissenting justices in United States ex rel. Hintopoulos v. Shaughnessy, 353 U.S. 72, 89-90 (1957); Jay v. Boyd, 351 U.S. 345, 361, 363, 376 (1956); United States ex rel. Eichenlaub v. Shaughnessy, 338 U.S. 521, 529 (1950).

134. United States ex rel. Accardi v. Shaughnessy, 347 U.S. 260, 269 (1954) (dissenting opinion).

135. United States ex rel. Johnson v. Shaughnessy, 336 U.S. 806, 820 (1949) (dissenting opinion).

136. Kessler v. Strecker, 307 U.S. 22, 38 (1939) (dissenting opinion). It should be noted that such a judicial tactic is conmon in other areas of administrative law. See K. Davis, Administrative Law TeXt $\$ 30.06$ (3d ed. 1972).

137. Powell v. McCormack, 395 U.S. 486, 506 (1969); Oyama v. California, 332 U.S. 633, 636 (1948); Chambers v. Florida, 309 U.S. 227, 228-29 (1940); St. Joseph 
tation proceedings the Constitution has long been the final authority on the rights of the parties. Fong Yue Ting v. United States ${ }^{138}-$ the case often cited as one of the first to recognize the power of Congress to protect national sovereignty by controlling immigrationdeclared that a court could interfere with congressional exercise of that power when "required by the paramount law of the Constitution."139 In later cases the Court was a bit more specific when it reaffirmed the supremacy of the Constitution. It pointed out individual constitutional rights to which the alien was entitled and which the Immigration Service must respect: the right to bail, ${ }^{140}$ the sixth amendment right to proper criminal procedure when an "infamous punishment" is to be imposed, ${ }^{141}$ the right to habeas corpus, ${ }^{142}$ and the first amendment right to free speech. ${ }^{143}$ The right most commonly cited (perhaps because it is the broadest) is the fifth amendment right to due process. Many times the Court has held that due process is essential if a deportation proceeding is to be valid. ${ }^{144}$ At a minimum, there must be adequate notice and an opportunity for the alien to be heard, ${ }^{145}$ the judge who presides at the hearing must be impartial, ${ }^{146}$ and the hearing itself must

Stockyard Co. v. United States, 298 U.S. 38, 51 (1936); Norris v. Alabama, 294 U.S. 587, 589-90 (1935); Crowell v. Benson, 285 U.S. 22, 46 (1932); Phelps v. United States, 274 U.S. 341,344 (1927).

138. 149 U.S. 698 (1893).

139. Id. at 713.

140. See Shaughnessy v. United States ex rel. Mezei, 345 U.S. 206, 210-13 (1953); Yanish v. Barber, 73 S. Ct. 1105 (1953); Carlson v. Landon, 342 U.S. 524 (1952).

141. Wong Wing v. United States, 163 U.S. 228, 233-34, 238 (1896).

142. Bridges v. Wixon, 326 U.S. 135, 156 (1945); Gegiow v. Uhi, 329 U.S. 3,9 (1915); Turner v. Williams, 194 U.S. 274, 294 (1905) (concurring opinion); Wong Wing v. United States, 163 U.S. 228, 233-34, 238 (1895); Len Moon Sing v. United States, 158 U.S. 538, 546-47 (1895).

143. See Turner v. Williams, 194 U.S. 274, 294 (1905) (concurring opinion). But cf. Kleindienst v. Mandel, 408 U.S. 753, 769-70 (1972), which limits this right in exclusion cases, where the governmental authority is nuch greater.

144. See Bridges v. Wixon, 326 U.S. 135, 156 (1945). See also notes 145-47 infra, and the acconipanying text.

145. Kwong Hai Chew v. Colding, 344 U.S. 590, 597 (1953); Jordan v. DeGeorge, 341 U.S. 223, 230-31 (1951); Wong Yang Sung v. McGrath, 339 U.S. 33, 50 (1950), modified, 339 U.S. 908 (1950); United States ex rel. Tisi v. Tod, 264 U.S. 131, 13233 (1924); The Japanese Immigrant Case, 189 U.S. 86, 100-02 (1903). See also Lem Moon Sing v. United States, 158 U.S. 538, 546-47 (1895).

146. Wong Yang Sung v. McGrath, 339 U.S. 33, $45-46$ (1950), modified, 339 U.S. 908 (1950).

There is some problem with the type of evidence that the Suprene Court will allow to be used against the alien in deportation hearings. Vajtauer v. Conum'r of Imunigration, 273 U.S. 103, 111, 113 (1927), United States ex rel. Tisi v. Tod, 264 U.S. 131, 132-33 (1924), and Bilokuniski v. Tod, 263 U.S. 149, 154 (1923), allow an alien's silence or improperly admitted evidence to be considered by the judge. Jay v. Boyd, 351 U.S. 345, 352-53 (1956), Shaughnessy v. United States ex rel. Mezei, 345 U.S. 206, 210 (1953), and United States $e x$ rel. Kanuff v. Shaughnessy, 338 U.S. 537, 544-46 (1949), allow confidential information to be used. But these cases should not be seen as ignor- 
be fair. ${ }^{147}$ Furthermore, because the Court believed that to subject an alien to the consequences of a decision unsupported by the factual evidence was to deny him due process, ${ }^{148}$ it developed the policy (discussed above) of allowing the lower courts to review determinations of fact. ${ }^{149}$

The task of insuring the supremacy of the Constitution falls on the lower federal courts. They are to review I.N.S. determinations when an alien claims that his constitutional rights have been violated. To help these courts cope with the difficult situation in deportation

ing the Constituion; for Vajtauer, Tisi, and Bilokumsky all emphasize the importance of allowing a fair hearing. There are several possible explanations for these cases. First, as Vajtauer points out, the constitutional linitations on self-incrimination and use of evidence are applicable only to criminal hearings and not to deportation proceedings, which are civil in nature. Second, the lax policy on evidence is in accord with the "reasonableness" test applied to the fact findings. As long as the evidence is accurate it matters little that it was admitted improperly. This can further be seen in GastellumQuinones v. Kennedy, 374 U.S. 469, 479-80 (1963), where the court held that, though I.N.S. could use the alien's silence against him, it could not rely solely on that silence to prove his deportability. Additional evidence of a more positive nature must be produced. Third, Mezei and Knauff, the cases which allow use of confidential information, are exclusion rather than expulsion cases. Shaughnessy v. United States ex rel. Mezei, 345 U.S. 206, 212-13 (1953), points out that were the alien being expelled he would lhave had a greater right to due proces. Jay v. Boyd, 351 U.S. 345 (1956), the only remaining case, is discussed in note 152 infra.

147. See United States $e x$ rel. Tisi v. Tod, 264 U.S. 131, 133-34 (1924); Ng Fung Ho v. White, 259 U.S. 276, 280, 284-85 (1922); Zakonaite v. Wolf, 226 U.S. 272, 27475 (1912); The Japanese Immigrant Case, 189 U.S. 86, 100-01 (1903); Wong Wing v. United States, 163 U.S. 228, 234 (1896). See also Shaughnessy v. United States ex rel. Mezei, 345 U.S. 206, 212 (1953); Wong Yang Sung v. McGrath, 339 U.S. 33, 45-46 (1950).

As inentioned above, the Court has long distinguished between cases in which an alien is entering the country and those in which he is already present here. The cases in which the Court recognizes constitutional rights and attempts to protect them in the face of the deportation power of Congress are most often expulsion cuses. The cases in which the Supreme Court's language limits the effect of the Constitution are overwhelmingly exclusion cases; e.g., Kleindienst v. Mandel, 408 U.S. 753 (1972), and Rosenberg v. Fleuti, 374 U.S. 449, 461 (1963). In part this is due to the territorial aspects of the fifth amendnent discnssed above. In part it is also due to the conceptual distinction between exclusion and expulsion. The former seeks to prevent a person from entering this country and coming into contact with the residents of this nation; the latter seeks to remove one who has already come into such contact. In the latter situation, the harm which is caused by contact has already occurred and the government's interest is less urgent.

148. See Vajtauer v. Commissioner of Immigration, 273 U.S. 103, 106 (1927); Kwock Jan Fat v. White, 253 U.S. 454 (1920); Zakonaite v. Wolf, 226 U.S. 272, 27475 (1912). See also St. Joseph's Stockyard Co. v. United States, 298 U.S. 38, 51-52 (1936); Ng Fung Ho v. White, 259 U.S. 276, 284 (1922).

149. The ex post facto provision of the Constitution, U.S. CoNST. art. I, $\$ 10$, does not apply to the usual immigration cases. See Harisiades v. Shaughnessy, 342 U.S. 580 (1950). However this is so not because iminigration cases are exempted from constitutional protection, but because as the Court pointed out, the ex post facto prohibition applies only to criminal cases. Id. at 594. Immigration proceedings are classified as civil rather than criminal in nature. 
cases where the power of Congress to deport is in conflict with the power of the courts to enforce the Constitution, the Supreme Court applied a technique it liad used in other areas of the law when the powers of administrative agencies and those of the courts clashed-that of conceptualizing constitutional questions as existing on a plane separate from that of the purely administrative questions. The lower courts' main duty is then to decide on which plane the case is more appropriately to be decided. If the issue is judged to be constitutional, there is to be no deference to the administrative agency. ${ }^{150}$ Through this technique the lower courts can obviate the question of deference to the agency and any mclination the court might liave to defer by focusing their entire attention on resolving the constitutional issue.

Accordingly, immigration cases have often been seen as having two conceptual levels: (1) the immigration level, controlled largely by the Congress; and (2) the constitutional level, controlled solely by the Court. An example of this technique is found in Kwong Hai Chew v. Colding ${ }^{151}$ where the court acknowledged the congressional authority over deportation, yet overturned the decision of the congressional agency (I.N.S.). It justified its action by saying, "[A]t the present stage of the instant case, the issue is not one of exclusion, expulsion, or deportation. It is one. . . of procedural due process."152

150. Crowell v. Benson, 285 U.S. 22 (1932), exemplifies this process. There an award had been made to an employee under the Longshoremen and Harbor Workers' Compensation Act, 33 U.S.C. $\$ \$ 901-950$ (1970) (originally enacted as Act of Mar. 4, 1927, ch. 509, $\S 1,44$ Stat. 1424). According to the act the decision was final; nevertheless, the Supreme Court allowed de novo review of the facts of the case. The Court reasoned that the statute did not limit the Court's ability to examine the facts "whenever that is deemed to be necessary to enforce a constitutional right properly asserted." Id. at 46. (Additional relevant cases are cited in Crowell.)

151. 344 U.S. 590 (1953).

152. Id. at 598. See also Umited States ex rel. Accardi v. Shaughnessy, 347 U.S. 260 (1954); McGrath v. Kristensen, 340 U.S. 162 (1950); Lem Moon Sing v. United States, 158 U.S. 538, 546-47 (1895) (which gives a very early example of this process by distinguishing between a "judicial question" and an immigration question).

Only one case, Jay v. Boyd, 351 U.S. 345 (1956), seriously questions the applicability of the Constitution to expression cases. In that case the Court commented that in questions of suspension of deportation the Attorney General has "unfettered discretion," and that he could have based his opinion on matters outside of the adininistrative record. Id. at 357-58. The government in Kleindienst v. Mandel, 408 U.S. 753, 769 (1972), interpreted this phrase as meaning that Jay had granted the government absolute discretion in certain matters, including relief from deportation. However, the government overlooked the qualification in Jay that "unfettered discretion" exists only "when such action would be reasonable." 351 U.S. at 358 . This implies that there will be some review of discretion.

But even assuming arguendo that the government's interpretation of Jay was correct, one need not accept the government's contention that the administrative discretion of the I.N.S. is complete, unfettered, and absolute; since that portion of the Jay opinion quoted above is no longer valid, and perbaps never was.

Jay was a $5-4$ decision in which the dissenting justices emphasized the unfairness 
The cases cited heretofore all involve proceedings not explicitly titled "discretionary." But the Constitution is no less the ultimate authority in cases directly involving acknowledged acts of discretion. Foti ${ }^{153}$ Carlson, ${ }^{154}$ and Yanish, ${ }^{150}$ hold that a court can review the facts upon which a discretionary decision is based, to insure that an alien's right to due process of law is not violated by subjecting him to a decision unsupported by the evidence. Carlson, ${ }^{156}$ Yanish $^{157}$ and Mezei ${ }^{158}$ recognize that an ahen in expulsion cases has an eighth amendinent right to bail even though according to 8 U.S.C. $\S 1252$ a bail is a matter

of the holding. Subsequent cases, e.g., Kimm v. Rosenberg, 363 U.S. 405, 408 (1960), and Hintopoulos v. Shaughnessy, 353 U.S. 72, 77 (1957), which are cited by the government in Mandel as continuing the Jay policy, do not characterize the Attorney General's discretion as being "unfettered." Kimm merely repeats the statement that an alien's silence can be given limited consideration by the Attorney General when exercising his discretion. And Hintopoulos would argue against the government's contention, since the Court examined the facts upon which the discretionary determination was made.

In regard to the Jay opinion it can be said that the cases relied on by the majorityShaughnessy v. United States ex rel. Mezei, 345 U.S. 206 (1953), and United States ex rel. Knauff v. Shaughnessy, 338 U.S. 537 (1950)-are exclusion cases. In such cases the government has much greater authority. The Court in Mezei explicitly makes the point that if the alien were being removed after entry, rather than being prevented from entry, more attention would have been given to his procedural rights. 345 U.S. at 212-13. Jay attempts to avoid the logical effect of this distinction by saying that the constitutional safeguards noted in Mezci and Kwong Hai Chew v. Colding, 344 U.S. 590 (1953), apply to deportation proceedings and not to discretionary determinations. 351 U.S. at 359. Such an argument is specious because it stands in opposition to the line of cases that have long required that the government deal fairly with ahiens being removed from this country. See United States ex rel. Accardi v. Shaughnessy, 347 U.S. 260, 265, 268 (1958), and note 163 infra. The Court has rarely distinguished between faimess in deportation proceedings and fairness in discretionary determinations. Further, as Foti v. I.N.S., 375 U.S. 217 (1963), later points out, "administrative discretion to grant suspension of deportation has historically been consistently exercised as an integral part of proceedings which have led to issuance of a final deportation order." Id. at 223 (einphasis added). Accord, Cheng Fan Kwok v. I.N.S., 392 U.S. 206, 214, 216 (1968). It would be "anomalous," as Gordon and Rosenfield put it, to separate the two parts of a deportation proceeding and require a different standard of fairness for each. GORDON \& ROSENFIELD, supra note 23 , $\$ 5.11$ d.

Therefore, it is understandable that the Court in Mandel refused to accept the governments claim to "unfettered" discretion (although characteristically also refusing to reject that claim expressly), examined the evidence supporting the immigration decision, and upheld it only after this examination on the ground that it was reasonable. The fact that the Court refused to accept the government's contention becomes even more significant when one considers that Mandel was an exclusion case where the Court should have had more reason to allow the government greater leeway. Because of such holdings the lower federal courts have not felt compelled to adhere to the Jay doctrine and instead have followed a fairer policy that antedated Jay and is exemplified in Kwong Hai Chew v. Colding, supra. See Davis, The Requirement of a Trial-Type Hearing, 70 HARV. L. REv. 193, 252-55 (1956).

153. Foti v. I.N.S., 375 U.S. 217, 228-29 (1963).

154. Carlson v. Landon, 342 U.S. 524, 539 (1952).

155. Yanish v. Barber, 73 S. Ct. 1105, 1106 (1953). 
within the Attorney General's discretion. ${ }^{159}$ Furthermore, there are other cases, such as McGrath v. Kristensen, ${ }^{160}$ which allow for constitutional supremacy by their use of the technique of conceptualization noted above in Kwong Hai Chew. ${ }^{161}$ As a result, the lower courts have generally accepted their duty of reviewing the constitutionality of discretionary determinations. ${ }^{162}$

It should be noted that the Supreme Court's policy of applying constitutional limits to "discretionary determinations" is quite understandable in view of the emphasis placed on fairness in the first alien cases $^{103}$ and in view of the comments made in Styria v. Morgan ${ }^{164}$ at about the same time. There the Court was concerned with the propriety of a decision by a ship's master which had resulted in damage. The Court stated that "[d]iscretion means a decision of what is just and proper in the circumstances," that it involves a "deliberate and considered judgment," and that a wrong result is not a true criterion of its proper exercise. ${ }^{105}$ It would thus be quite logical for the Court, which

156. Carlson v. Landon, 342 U.S. 524, 540-41, 543 (1952).

157. Yanish v. Barber, 73 S. Ct. 1105, 1108 (1953).

158. Shaughnessy v. United States ex rel. Mezei, 345 U.S. 206, 215 (1952).

159. It is important to note that an alien's eighth amendment right to bail, like that of a cilizen, is subject to certain limits, such as consideration of the alien's threat to the security of the nation. Carlson v. Landon, 342 U.S. 524, 544-45 (1952). However, these limitations should not be seen as restrictions on the application of the Constitution to deportation cases since they are limitations inherent in the eighth amendment itself. As the Court in Carlson remarked, the legislative and executive power to control aliens is "subject to judicial intervention under the paramount law of the Constitution." II. at 537.

160. 340 U.S. 162,169 (1950). See also United States ex rel. Accardi v. Shaughnessy, 347 U.S. 260 (1958).

161. Thus, the administrative determination was overturned on the ground that an alien has a "right" to have the I.N.S. exercise its discretion independent of intiial interference by the Attorney General. The dissent claimed that the right to require an exercise of discretion was not a legal right of the same stature as other legal rights and that the majority was, in effect, expanding the concept of "legal right" to an area where a private right was not guaranteed either by statute or by the Constitution. Id. at 26970.

162. See generally Wong Wing Hang v. I.N.S., 360 F.2d 715, 718 (2d Cir. 1965); Mastrapasqua v. Shaughnessy, 180 F.2d 999 (2d Cir. 1950); Alexiou v. McGrath, 101 F. Supp. 421, 424 (D.D.C. 1951); Thompson, Developments in the Law: Immigration and Nationality, 66 HARv. L. REv. 643, 701 (1953).

163. See Turner v. Williams, 194 U.S. 279, 295 (1904) (concurring opinion); The Japanese Immigrant Case, 189 U.S. 86, 100-01 (1903); Wong Wing v. United States, 163 U.S. 228, 233-34, 238 (1896); Fong Yue Timg v. United States, 149 U.S. 698, 724 (1893); Yick Wo v. Hopkins, 118 U.S. 356, 366-70 (1886).

164. 186 U.S. 1 (1901).

165. Id. at 9-10 (emphasis added). The Court was concerned specifically with whether the exercise of discretion should result in liability; however, the statement regarding discretion appears to be general enough to apply to the area of administrative discretion. In fact, the last part of the statement has been incorporated into administrative law policy-a discretionary determmation is not overturned by the courts on review simply because it is wrong. 
intended fairness to aliens and which had as its primary responsibility enforcement of the Constitution, to expect that I.N.S., in its "deliberate and considered judgment" of what was "just and proper," would observe the limitations of the Constitution, and to intervene when I.N.S. failed to do so.

\section{Conclusion}

The statements in Prassinos v. District Director of the Immigration and Naturalization Service ${ }^{166}$ to the effect that the I.N.S. could either deport an alien who had a cause of action without allowing him an opportunity to pursue his claim or could put certain conditions on a grant of discretionary relief which would "chill" the effective exercise of his right to sue, were incorrect assessments of the authority of the I.N.S. and did not give due consideration to the riglits of the alien. The Supreme Court, despite broad comments that the regulation of immigration is under the control of Congress, has nevertheless allowed extensive review of the manner in which Congress (through the I.N.S.) exercises that control. If the I.N.S., influenced by the statements in Prassinos, were to order an alien's deportation without allowing him an opportunity to pursue a claim, or if it were to put conditions on a grant of discretionary relief which would "chill" the exercise of the right to sue, a federal court, in keeping with the third guideline set forth above, ${ }^{167}$ should throughly review the action taken, determine whether the I.N.S. had indeed nullified or restricted the alien's constitutional right, and thereafter grant to the alien the rehief which is appropriate (whether it be delay of deportation or extension of voluntary departure). The fact that a constitutional clain has been raised takes the case out of the usual class of cases involving deportation orders or discretionary decisions and gives the court both greater authority to examine the constitutional issue separate from issues of deportabihty and eligibility for discretion, and greater freedom to overturn the I.N.S. decision if the court feels that such a reversal is warranted to allow the full exercise of the right claimed.

In Hong v. Agency for International Development ${ }^{168}$ the Court of Appeals for the Ninth Circuit did just this. An alien found to be deportable had requested a stay of deportation to allow him time to pursue a contract clann. The Immigration Service, however, ordered

166. 193 F. Supp. 416,420 (N.D. Ohio 1960), aff'd, 289 F.2d 490 (6th Cir.), cert. denied, 366 U.S. 966 (1961).

167. If a reviewing court wishes, it can avoid the entire question of constitutionality by means of statutory interpretation by holding that the Immigration Act does not allow the I.N.S. to restrict an alien's right to sue, thereby using the second guideline to overturn the determination.

168. 470 F.2d 507 (9th Cir. 1972). 
his immediate deportation. The circuit court granted the stay of deportation, reasoning as follows. The order deporting the alien was valid, but the alien had a contract claim which was also valid. This claim could not be adjudicated by I.N.S. since its authority is limited to determinations of deportability. Therefore, unless the court itself delayed the deportation, a legal right would have been lost. ${ }^{169}$ The circuit court would not allow the I.N.S. in the performance of its duty to interfere with the alien in the exercise of his right.

\section{Balancing the Interests}

Supporters of the Immigration Service will correctly point out that the fact that an alien's constitutional right is being restricted does not by itself compel an appellate court to overturn the administrative decision. The court must also determine for itself that the case presents a justiciable issue and that the alien's interests, which are being restricted, outweigh the governmental interests involved. Otherwise, the court must allow the administrative action to stand regardless of its effect on the alien's rights. However, in a case where the I.N.S. has nullified or restricted the alien's right to sue in the manner described above, the issue presented is justiciable; and the interests of the alien do in fact outweigh the interests of the government.

In the case of Kleindienst $v$. Mandel, ${ }^{170}$ a group of American citizens were seeking to bring Ernest Mandel, a Marxist theorist and a self-avowed Communist, into the country to speak at a conference. Since Mandel was a Communist and was, therefore, excludable from entry, he requested that the I.N.S. (in its discretion) waive his inadmissiblity. The Service refused to do so and denied him a visa on the ground that during a previous visit to the United States he had flagrantly abused the opportunity afforded to him to express his views. The plaintiffs challenged the constitutionality of the I.N.S. decision, claiming that although Mandel had no personal right to enter the U.S., the citizens of the U.S. had a first amendment right to have him enter and to hear him explain his views. The Supreme Court rejected this argument and affirmed the denial of the visa. The majority emphasized that it was essential to national sovereignty to allow the Congress this power to prevent certain aliens from entering and that first amendment rights should not interfere with the reasonable congressional exercise of that power. The Court was faced with a choice between two equally important constitutional provisions which were mutually exclusive. That it refused to choose and instead deferred to the decision

169. Id. at 508 .

170. 408 U.S. 753 (1972). 
of Congress should not be surprising since it is a common practice of the Supreme Court to avoid issues that are not justiciable and are more appropriately handled by the representative branches of the government. A decision that requires a choice between conflicting general principles is not an appropriate decision for the court. ${ }^{171}$

However, the above situation does not exist when an alien seeks delay of deportation or voluntary departure until he has had a chance to get his suit underway. In such a case, the governinent interest and the alien's interest are not mutually exclusive. The alien is simply asking for a reasonable amount of time. He is not challenging the government's authority to control immigration; rather he is challenging only the manner in which the government exercises that authority, and is requesting that the government make some accomodation for the constitutional rights of those persons with whom the government deals. Thus, the government's interest is not the broad non-justiciable interest of Kleindienst v. Mandel. Rather, the governmental interest may be characterized in one of two ways: (a) the interest in removing an alien a few months sooner than he would otherwise be removed if he had no claim to a suit; or (b) the interest in insuring that the government has absolute, unreviewable authority to expel individuals from the country.

Once the issue has been posed in this manner the Supreme Court can balance the specific competing interests and come to a decision, simce this is the type of issue that the Court has traditionally addressed and in which it has "expertise."172 The interest of the individual is his right to sue. It is a right which the Court recently held, in Boddie $v$. Connecticut, ${ }^{173}$ to be an essential part of due process of law, and to be so commonly acknowledged that the Court has rarely been called upon to rule on it. If the alien is demied access to the court, he is effectively deprived of whatever personal or property interest he wished to assert. This right inust be contrasted with the first amendment right raised in Kleindienst v. Mandel. There the right asserted was not the right of an alien seeking entry, but rather the right of American residents to hear the ahen. This would seem to be a less important right than others which might be claimed. The Court indirectly indicated this by explicitly refusing to extend its holding to include first amendment claims raised in other situations. ${ }^{174}$

171. See Powell v. McCormack, 395 U.S. 490, 517 (1969); Kwong Hai Chew v. Colding, 344 U.S. 590, 597-98 (1953); Harisiades v. Shaughnessy, 342 U.S. 580, $589-$ 90 (1952); Wong Yang Sung v. McGrath, 339 U.S. 33, 46 (1950); Fong Yue Ting v. United States, 149 U.S. 698, 712 (1893). See also K. Davis, Administratrve LAw TexT $\$ 28.05$ (3d ed. 1972).

172. K. Davis, Administrative Law Text $\$ \S 28.06,28.07$ (3d ed. 1972).

173. 401 U.S. $371,374-75$ (1971).

174. 408 U.S. 753,770 (1972). 
The first of the two governmental interests-renoving the alien in the shortest time possible-has been recognized as a valid interest. On several occasions the Suprene Court and the federal courts have alluded with approval to congressional attempts to limit dilatory actions by the aliens. ${ }^{175}$ But when the courts have alluded to this interest, they have not stressed its fundamental importance as the Boddie opinion did with regard to the right to sue, presumably because the need to prevent dilatory maneuvers is not of paramount importance. As seen above, the Supreme Court has prevented summary deportation and required that I.N.S. delay deportation long enough to give an alien the procedural protections of the law. When the alien files an appeal with a federal court against a determination of deportability, deportation is again delayed. ${ }^{176}$ When an alien claims U.S. citizenship or marriage to an American citizen, the deportation process is delayed further. ${ }^{177}$ Similarly the process will be delayed if an alien is prosecuted criminally or civilly. ${ }^{178}$ He will not be deported until completion of the judicial proceeding and satisfaction of the judgment or sentence. Even inore important is the fact that at present I.N.S. claims that, acting on its own discretion, where an alien requests a delay to complete a pending suit, the delay is given in most cases. An interest which allows so many exceptions to its assertion can hardly be considered vitally important.

The other governmental interest-the protection of the governinent's absolute, non-reviewable control over discretionary decisions to deport-is also less than compelling. First, in this case national sovereignty is not at stake as it is in exclusion cases. The alien is already present, and all that is at stake is a few additional months of presence. Second, while the courts have often used broad statements to characterize I.N.S. discretion, they have always applied some limit to its exercise, even if it was only a requirement of "reasonableness." Moreover, inany Supreine Court opimions have restricted the scope of discretion by such ineasures as allowing thorough review of the facts on which the decision is based, by narrowly interpreting the statutes that give I.N.S. its authority, and by removing constitutional issues from the consideration of the officials exercising the discretion. Thus, it is clear that I.N.S. discretion has never been absolute. I.N.S. should therefore

175. See Foti v. I.N.S., 375 U.S. 217, 225-26 (1963); Braude v. Wirtz, 350 F.2d 702, 705 (9th Cir. 1965); Adame v. I.N.S., 349 F. Supp. 313, 315 (N.D. Ill. 1972); Prassinos v. Dist. Director I.N.S., 193 F. Supp. 416, 420 (N.D. Ohio 1960), aff'd, 289 F.2d 490 (6th Cir. 1961), cert. denied, 366 U.S. 966 (1961). See also In re Paduano, 13 I. \& N. 658, 660 (Dec. 1971); GoRDON \& ROSENFIELD, supra note 23, § 8.9Af; H.R. Doc. No. 1086, 87th Cong., 1st Sess. 2966 (1961).

176. See GORDON \& ROSENFIELD, supra note $23, \S \S 8.7 \mathrm{e}, 8.9 \mathrm{c}$.

177. Id. $\S \S 5.16 \mathrm{a}, 8.30$.

178. Id. $\$ 5.16 \mathrm{c}$. 
not be allowed to assert an interest it has never had in opposition to the constitutional right of an alien to prosecute a civil suit.

Any interest advanced by the I.N.S. in opposition to an alien's riglit to sue must be evaluated in light of two general policies that the Supreme Court las applied in other immigration situations. The first is the Court's policy of refusmg to allow government claims of inconvenience or additional expense to interfere with fair treatment of aliens. ${ }^{179}$ The second is the Court's policy of accommodating conflicting constitutional provisions in order to prevent one from armulling the other. This second policy has led the Court in many of the decisions inentioned above to construe immigration statutes narrowly so as to preserve alien rights. This is illustrated by the oft-repeated statement of the Court in Fong Haw Tan v. Phelan that:

To construe this statutory provision less generously to the alien might find support in logic, but since the stakes are considerable for the individual we will not assume that Congress meant to trench on his freedom beyond that which is required by the narrowest of several possible meanings of the words used. 180

This second policy can be considered an extension of a broader Suprenie Court policy of attempting at all times to interpret the acts of Congress in such a manner as not to thwart the purposes of the Constitution. ${ }^{181}$

Both of these policies call for allowing an alien sufficient time to conclude prosecution of a civil suit. Although this might result in some administrative inconvemence, it is eminently nore fair to allow the delay than to deny to the alien the only recogmized lawful and peaceful means by which he can protect himself and his property from abuse. Even conceding arguendo the importance of the specific governmental interests described above, they should not be protected at the expense of coinpletely destroying the alien's imterest. Rather, these respective interests should be accommodated. A concrete recommendation for such an accommodation is presented below.

If there remain any doubts as to the propriety of allowing a court to interfere with a discretionary decision in this situation, perhaps these doubts can be assuaged by considering the general tenor and spirit of the Supreme Court decision in St. Joseph Stockyard Co. v. United

179. Wong Yang Sung v. McGrath, 339 U.S. 46 (1950), best exemplifies this policy. This case dealt with a situation in which the fairness was required by the Administrative Procedure Act. Presumably, the same sentiment would be present in a situation where fairness is required by the Constitution.

180. 333 U.S. 6, 10 (1948). Accord, I.N.S. v. Errico, 385 U.S. 214, 225 (1966);

Costello v. I.N.S., 376 U.S. 120, 128 (1964).

181. See Phelps v. Umited States, 274 U.S. 328, 344 (1928). 
States, ${ }^{182}$ which was decided during the period when the Court was quickly expanding recognition of limits on the authority of the I.N.S. ${ }^{183}$ In St. Joseph Stockyard the Court sought to enforce some judicial review over administrative decisions and to restrict the power of administrative agencies to affect constitutional rights:

But to say that the administrative findings of fact may be made conclusive where constitutional rights of liberty and property are involved, although the evidence clearly establishes that the findings are wrong and constitutional rights have been imvaded, is to place those rights at the mercy of administrative officials and seriously to impair the security inherent in our judicial safeguards. That prospect, with our multiplication of administrative agencies, is not one to be lightly regarded. ${ }^{184}$

\section{Recommendation}

To insure the free exercise of the right to sue yet to avoid the creation of a loophole that might easily be abused by aliens, the following recommendations are offered.

The present I.N.S. practice should be retained as the mitial stage. At this point the alien should inform the Service of his pending or planned suit and request an appropriate form of relief-a stay of deportation or, if he is eligible, an extension of voluntary departure-to allow him sufficient time to pursue his claim. If the alien's request is demed or subjected to unsatisfactory conditions, the I.N.S. should then request a declaratory judgment from a federal court approving its decision. (If this should prove to be impractical or too unorthodox, the burden might be placed on the alien to file for a declaratory judgment or some other means of judicial review of the order.) At the judicial hearing, the alien should have the burden ${ }^{185}$ of showing by testimony, deposition, or both, that his claim or suit is indeed valid and that it is neither collusive nor a shain brought with the primary intent of delaying deportation. Important considerations for the court might be the identity of the defendants, the nature of the cause of action, and the nature of the alien's efforts to retain an attorney, file his claim, and pursue his claim vigorously. If the alien demonstrates to the court that his claim or suit is valid, the court should, without hesitation, grant him that form of relief appropriate under the circumstances which would fully protect the exercise of the right to sue. That is to say the alien should at least be granted a stay of deportation. If the alien

182. 298 U.S. 38 (1936).

183. Davis, supra note 104 , $\$ 28.10$, at $48-49$.

184. 298 U.S. 38, 52 (1936).

185. Generally, the person claiming the right has the burden of showing that the right has been violated. See, e.g., St. Joseph's Stockyard Co. v. United States, 298 U.S. 38,72 (1936). 
would have been granted voluntary departure if he had not had a suit pending, he should be given voluntary departure. If a voluntary departure has been given to him which has a date or conditions that would affect the right to sue, the court should declare the conditions void and extend the date. In any event, the fact that the alien has a suit or claim pending and wishes to pursue it should not subject him to any harsher treatment than he would have received otherwise. This would not only insure an opportunity to sue but would also eliminate any "chilling" factors.

The stay of deportation or extension of voluntary departure need not in all cases last until the actual date of trial. It only need allow sufficient time for the alien to nove his suit far enough along that his presence is no longer needed. This would normally occur, for example, when he lias obtained an attorney, confronted the defendant, and aided his attorney in identifying witnesses, obtaining relevant testimony or evidence, establishing damages and providing the information that is required to plead in forma pauperis. When his presence is no longer essential, the alien should leave the country, but should first be given advance guarantee of parole into the Umited States so that he might return for the trial. ${ }^{186}$ If the I.N.S. still fears that the alien might overstay after the completion of the suit, it can, in anticipation, completely process a deportation order (or an exclusion order if the alien is paroled into the country) and refrain from filing it until the alien in fact delays longer than is reasonably necessary. At that time he can be immediately deported. ${ }^{187}$

In this manner, both the opportunity for abuse and the length of the alien's time in the country will be kept to a minimunı while simultaneously providing for the effective exercise of the alien's right to sue.

\section{CONCLUSION}

The right to sue is guaranteed to all persons physically present withm the borders of the United States. This is so even if the person is unlawfully present in the country. Although an illegal alien has violated certain provisions of the Immigration and Nationality Act and thereby become subject to the prescribed penalties-deportation and possible criminal punishment, he is not stripped of all his constitutional rights. He is an "illegal alien," but his "illegality" refers only to his immigration status and not to his constitutional status.

The state courts in general recognize this fact, though a few state courts refuse to acknowledge that the alien's right to sue is a personal,

186. Such advance approval is allowed under 8 U.S.C. $\$ 1182(1970)$.

187. See GoRDon \& ROSENFIELD, supra note 23 , $\$ \S 5.14,5.16,5.18,5.19$. 
constitutional right, rather than a right which the court allows him to exercise on the basis of comity. Even if he is denied access to a court, however, an alien seeking civil redress can seek a writ of nuandamus front the federal courts to conipel access to the court.

The nuajor obstacle preventing the alien from exercising his right is in the federal courts. Though the federal courts generally recognize an illegal alien's standing to sue, all too often, as in Prassinos, they are willing to allow the Immigration Service to nullify an alien's right on the ground that the granting of sufficient time to exercise the right is a discretionary matter with the I.N.S. These courts are so impressed by the vital function that the I.N.S. fulfills in protecting national sovereignty that they defer almost blindly to its discretionary judgment. But in so doing these courts ignore the limitations that the Supreme Court has always placed on the exercise of administrative discretion in immigration cases. By allowing a reviewing court to overturn a discretionary decision if the decision was based on an incorrect interpretation of the law or on facts which were not proven by clear, convincing, and probative evidence, or if the decision itself was not reasonable in light of those facts, the Supreme Court has confined discretionary authority to a small area ${ }^{188}$ and has set conditions on its exercise within that area. The Court has further narrowed the scope of discretionary authority to exclude constitutional issues. Thus, the authority of the I.N.S. is meant to enconipass nuatters of immigration only.

There is no constitutional requirement that courts must defer blindly to the discretion of the I.N.S. Were the Court to consider the interests of the alien and weigh thein against the government's interests in the traditional "balancing" procedure, there is little doubt that the alien's interest would be found more compelling. The fundamental importance of the right to sue has recently been reaffirmed by the Supreme Court in Boddie v. Connecticut. Government interests, however, either in seeking to remove the ahen in the shortest time possible or in asserting its unreviewable authority over discretionary inatters, have not received great weight in past Suprene Court opmions.

Accordingly, the federal courts should not hesitate to recognize the illegal alien's right to sue or to grant him any relief froni I.N.S. orders necessary to insure the effective exercise of that right. It does not matter whether a court justifies its decision on the ground that it is an abuse of discretion for I.N.S. to refuse an alien's request for discretionary relief when a constitutional right depends on such relief, or on the ground that the Immigration and Nationality Act was not in-

188. "Small" is meant from a theoretical point of view. Only certain types of situations can be handled. The number of cases that falls within this theoretical area is quite large. 
tended to give an immigration official authority to affect the constitutional rights of aliens. However the decision is justified, the court must give effect to the alien's right to sue.

It is well recognized that illegal aliens are quite vulnerable to abuse because of their poverty, lack of formal education, and ignorance of the Enghish language. Therefore it is especially important that the state and federal courts acknowledge their right to seek legal redress and not allow any individual or agency to hinder the exercise of that right. 